\title{
Using residual income to refine the relationship between earnings growth and stock returns
}

\author{
Sudhakar Balachandran • Partha Mohanram
}

Published online: 19 August 2011

(C) Springer Science+Business Media, LLC 2011

\begin{abstract}
We use residual income (RI) to decompose earnings growth into growth in RI, growth in invested capital and other components and use this decomposition to explain stock returns. Our approach provides a significant increase in explanatory power vis-à-vis a regression of returns on levels and changes in earnings. While the market values growth in RI more than growth in invested capital, it still undervalues growth in RI and overvalues growth in invested capital. Earnings growth from growth in RI is more persistent, while earnings growth from growth in invested capital is more likely to reverse. Future returns are positively associated with growth in RI and negatively associated with growth in invested capital. A trading rule based on these findings generates significant hedge returns that persist after controlling for known risk factors. Hence, RI, a measure long recommended by accountants, allows investors to differentiate and evaluate different sources of earnings growth.
\end{abstract}

Keywords Earnings growth - Residual income - Growth in residual income · Growth in invested capital

JEL classification $\mathrm{M} 40 \cdot \mathrm{M} 41 \cdot \mathrm{M} 44$

\section{Introduction}

Earnings and earnings growth have long been viewed both theoretically and empirically as fundamental determinants of stock returns (Easton and Harris 1991;

\footnotetext{
S. Balachandran $(\square)$

Columbia Business School, New York, NY 10027, USA

e-mail: svb34@columbia.edu

P. Mohanram

Rotman School of Business, Toronto, ON M5S-3E6, Canada

e-mail: partha.mohanram@rotman.utoronto.ca
} 
Ali and Zarowin 1992; Easton et al. 1992; Ohlson and Juettner-Nauroth 2005). In this paper, we use the concept of residual income to decompose earnings growth into growth in residual income, growth in invested capital, and other components. Using this decomposition, we ask the following. First, are we better able to explain cross sectional variation in returns using this decomposition? Second, do growth in residual income and the other components of earnings growth have different associations with returns? Third, does the market fully appreciate the implications of growth in residual income and the other components of earnings growth, or do these components predict future stock returns?

Residual income (RI) seems a natural point of departure to refine the empirical relationship between earnings growth and stock returns. Accounting scholars have long criticized accounting earnings as an incomplete measure of firm profitability from the shareholders' perspective since accounting earnings do not reflect the opportunity cost of the capital employed (Solomons 1965; Dearden 1972; Morse and Zimmerman 1997; Horngren et al. 2006). They present RI as a better proxy for economic profits as it includes a charge for capital employed. Anthony (1973) notes that firms often consider the cost of capital for internal decision making, arguing that "In management accounting it is quite usual to take into account the cost of equity capital; indeed, unless it did so, a company's management would have difficulty in planning effectively and maintaining control." He supports the use of RI to analyze firm profitability by arguing that "the financial community would be better able to judge the company's results if the reports it analyzed recognized these costs."

Subsequent research in both managerial and financial accounting has analyzed the usefulness of RI. Rogerson (1997), Reichelstein (1997), and Dutta and Reichelstein (2002) show theoretically that contracts based on RI with appropriate accrual accounting can achieve goal congruence between owners and managers. Empirically, Wallace (1997) and Balachandran (2006) show that firms' investment decisions are likely to be better aligned with shareholder interests after the implementation of RI-based compensation contracts. Theory work in financial accounting has used residual income to develop structural models to value firms (Ohlson 1995; Feltham and Ohlson 1995). These residual income valuation models have been empirically used to estimate the intrinsic value of the firm (Frankel and Lee 1998) and estimate implied cost of capital (Gebhardt et al. 2001).

Given the vital importance accorded to RI by prior literature, we seek to use it as a basis to refine the relationship between returns and earnings. In our refinement, we decompose earnings growth into growth in RI, growth in invested capital and other components. We incorporate this decomposition of earnings growth into the standard Easton and Harris (1991) specification, which expresses stock returns as a function of the level of earnings and growth in earnings.

We first find that the RI-based decomposition explains more of the crosssectional variation in stock returns than does the Easton and Harris (1991) specification. Further, while both growth in RI and growth in invested capital are positively associated with returns, the relationship is stronger for growth in residual income. These results highlight the incremental value of using the RI-based 
decomposition. Moreover, they suggest that the stock market views earnings growth arising from growth in RI as more valuable.

To understand why the market views growth in residual income as more valuable, we analyze the persistence of earnings growth. We find that earnings growth is likely to be more persistent when the proportion of earnings growth coming from growth in residual income is greater and more likely to reverse when the proportion of earnings growth coming from growth in invested capital is greater.

We next analyze the relationship between the components of earnings growth and future returns. We find that growth in RI is positively associated with future returns, while the growth in invested capital is negatively associated with future returns. This suggests that the market does not contemporaneously impound the information in the components of earnings growth appropriately, underreacting to growth in RI and overreacting to growth in invested capital. To analyze the economic significance of our results, we test a trading strategy based on going long in firms with the most growth in residual income and going short in firms with the greatest growth in invested capital. We find that such a strategy generates economically meaningful hedge returns that are consistent across time, robust to controlling for risk factors, and incremental to other documented anomalies.

To summarize, our results validate the RI-based decomposition of earnings growth to refine the relationship between earnings and returns. This has implications for prior research, which finds that RI has only a minimally incremental association with stock returns over and above earnings (Biddle et al. 1997; Chen and Dodd 1997). We show that the utility of RI lies not as a competing metric to earnings, but as an effective conditioning variable that separates out different components of earnings growth.

In a related paper, Balachandran and Mohanram (2010) use the RI-based decomposition of earnings growth developed here to test whether boards consider the differential valuation implications of the components of earnings growth when determining CEO compensation. They find that boards in fact place a greater weight on earnings growth from growth in invested capital as opposed to earnings growth from growth in RI and conclude that the boards are, in a sense, incentivizing CEOs to destroy shareholder value.

The remainder of this paper is organized as follows. Section 2 develops our empirical specification and research design. Section 3 describes our sample selection and provides descriptive statistics. Section 4 presents the results of the paper. Section 5 concludes.

\section{Research design}

2.1 The relationship between returns and earnings

We start with the specification developed in Easton and Harris (1991), which combines two valuation perspectives that view firm value or stock price as a function of either book value or accounting earnings. Hence, returns (change in price) can be viewed as a function of earnings (change in book value) and change in 
earnings. This is also the first-differenced form of models in Ohlson (1995) and Feltham and Ohlson (1995), which express price as a function of book value and earnings. Easton and Harris (1991) express the relationship between returns and earnings as:

$$
\operatorname{RETM}_{\mathrm{t}}=\alpha_{0}+\alpha_{1} \mathrm{NI}_{\mathrm{t}}+\alpha_{2} \Delta \mathrm{NI}_{\mathrm{t}}+\varepsilon
$$

where $\mathrm{RETM}_{\mathrm{t}}$ is a measure of market-adjusted returns.

While the Easton and Harris (1991) framework relies on earnings growth, it does not distinguish between the different sources of earning growth. It assumes that all earnings growth is equally valuable to shareholders. However, in reality, earnings growth from certain sources may be more valuable than earnings growth from other sources. In the following sub-section, we argue that decomposing earnings growth using residual income might help in separate out components of earnings growth that differ in their inherent value.

2.2 Why use residual income to refine the relationship between returns and earnings?

Accountants have long cautioned that earnings growth should be interpreted with care because the income statement does not reflect the full cost of capital invested in the firm. This can cause income to grow even for firms that invest in negative NPV projects. For instance, a firm might grow net income by investing in projects that generate enough profits to cover the cost of debt but not the total cost of capital. Similarly, a firm might hoard excess cash on its balance sheet and earn interest from this excess cash, increasing net income, but generating returns lower than the opportunity cost of shareholder funds. The basic model used to analyze the relationship between returns and earnings does not have the ability to distinguish between firms that increase accounting earnings while increasing shareholder value and firms that may be increasing accounting earnings but potentially destroying shareholder value.

Residual income is a natural starting point to refine the relationship between earnings and stock returns. If returns to shareholders are a function of growth in the economic profitability of the firm, then incorporating a superior measure of economic profitability can potentially improve the ability to explain stock returns. Residual income starts with accounting income and incorporates a charge for the opportunity cost of the capital employed, thereby correcting an inherent incompleteness in accounting earnings. Since the 1960s, accounting scholars have viewed residual income as a more appropriate indicator of firm profitability (Solomons 1965; Dearden 1972; Morse and Zimmerman 1997; Horngren et al. 2006). Rogerson (1997) shows theoretically that it is appropriate to "impute interest costs at the firm's cost of capital when using income as a performance measure for management." He concludes that "the current wave of enthusiasm for residual income and EVA measures seems justified."

Rogerson (1997), however, argues that the expenses (depreciation plus interest) associated with the usage of an asset that is equally productive throughout its lifetime ought to be constant across all periods. However, the imputed interest 
(capital charge in residual income) is higher initially when book values are high, while depreciation is typically either straight line or accelerated. The higher initial capital charge means that residual income is often understated in the early stages of an asset's life. Baldenius et al. (1999), however, show that, while the level of residual income may be biased downwards initially, changes in residual income preserve the valuation relationship between residual income and the net present value of a firm, independent of the depreciation method. This has implications for our RI-based refinement of the Easton and Harris (1991) model as it suggests that we ought to focus on decomposing the change in net income into the change in residual income and other components, rather than decomposing the level of net income into residual income and other components.

\subsection{Using residual income to decompose earnings growth}

The prior research has typically defined RI as net operating profit after tax (NOPAT) for the period less a charge for invested capital at the beginning of the period, which is typically represented as a weighted average cost of capital (WACC) times the capital invested (IC). As NOPAT is the sum of net income and after-tax interest, we can express residual income (henceforth $\mathrm{RI}$ ) as:

$$
\mathrm{RI}_{\mathrm{t}}=\mathrm{NI}_{\mathrm{t}}+\mathrm{INT}_{\mathrm{t}} *(1-\mathrm{t})-\mathrm{WACC}_{\mathrm{t}} * \mathrm{IC}_{\mathrm{t}-1} .
$$

where NI is GAAP net income for the period, $\mathrm{INT}_{\mathrm{t}}$ is interest expense, and $\mathrm{t}$ is the tax rate.

Correspondingly RI in the prior period is:

$$
\mathrm{RI}_{\mathrm{t}-1}=\mathrm{NI}_{\mathrm{t}-1}+\mathrm{INT}_{\mathrm{t}-1} *(1-\mathrm{t})-\mathrm{WACC}_{\mathrm{t}-1} * \mathrm{IC}_{\mathrm{t}-2} .
$$

Combining (2), and (3), we can express change in RI as:

$$
\Delta \mathrm{RI}_{\mathrm{t}}=\Delta \mathrm{NI}_{\mathrm{t}}+\Delta \mathrm{INT}_{\mathrm{t}} *(1-\mathrm{t})-\mathrm{WACC}_{\mathrm{t}} * \mathrm{IC}_{\mathrm{t}-1}+\mathrm{WACC}_{\mathrm{t}-1} * \mathrm{IC}_{\mathrm{t}-2} .
$$

where $\Delta$ refers to the change in a variable.

Add and subtract $\mathrm{WACC}_{\mathrm{t}} * \mathrm{IC}_{\mathrm{t}-2}$ to the above expression to obtain:

$$
\begin{aligned}
\Delta \mathrm{RI}_{\mathrm{t}}= & \Delta \mathrm{NI}_{\mathrm{t}}+\Delta \mathrm{INT}_{\mathrm{t}} *(1-\mathrm{t})-\mathrm{WACC}_{\mathrm{t}} * \mathrm{IC}_{\mathrm{t}-1}+\mathrm{WACC}_{\mathrm{t}} * \mathrm{IC}_{\mathrm{t}-2} \\
& -\mathrm{WACC}_{\mathrm{t}} * \mathrm{IC}_{\mathrm{t}-2}+\mathrm{WACC}_{\mathrm{t}-1} * \mathrm{IC}_{\mathrm{t}-2} .
\end{aligned}
$$

Reorganizing the above expression and solving for $\Delta \mathrm{NI}_{\mathrm{t}}$ we obtain:

$$
\Delta \mathrm{NI}_{\mathrm{t}}=\Delta \mathrm{RI}_{\mathrm{t}}+\Delta \mathrm{IC}_{\mathrm{t}-1} * \mathrm{WACC}_{\mathrm{t}}-\Delta \mathrm{INT}_{\mathrm{t}} *(1-\mathrm{t})+\mathrm{IC}_{\mathrm{t}-2} * \Delta \mathrm{WACC}_{\mathrm{t}} .
$$

This decomposition is potentially helpful because empirically it explicitly considers earning growth in terms of a growth in RI component that incorporates the cost of capital, as well as other components. Consider the terms in Eq. 6.

- $\Delta \mathrm{RI}_{\mathrm{t}}$ : Earnings growth from growth in RI. It is change in net income that exceeds the incremental cost of capital invested. This growth in the RI component is increasing only when earnings changes are greater than the incremental cost of capital invested. Even if earnings growth is positive, the 
growth in the residual income component could be negative if the earnings growth does not exceed the incremental capital charge.

- $\quad \mathrm{IC}_{\mathrm{t}-1} * \mathrm{WACC}_{\mathrm{t}}$ : Earnings growth from growth in invested capital. It equals the change in invested capital multiplied by the weighted average cost of capital. It represents earnings growth one would expect if the firm earned the cost of capital on new investment.

- $\Delta \mathrm{INT}_{\mathrm{t}} *(1-\mathrm{t})$ : Earnings growth from the change in after-tax interest expense. This could be either because of increased debt or increased cost of debt. As NI is after interest and taxes, an increase in interest expense lowers the growth in NI, all else being equal.

- $\mathrm{IC}_{\mathrm{t}-2} * \Delta \mathrm{WACC}_{\mathrm{t}}$ : Earnings growth from the change in cost of capital. Cost of capital could change due to changes in risk, or capital structure among other factors.

The RI-based decomposition above has the advantage of dividing earnings growth into additive components, allowing one to compare the relative coefficients between the different components and make assessments about differential valuation. Harris and Nissim (2006) also analyze the valuation of earnings growth derived from different sources. Their tests do not use a formal decomposition but instead use the change in return on invested capital $\left(\Delta \mathrm{ROIC}_{\mathrm{t}}\right)$ as a proxy for growth from increased profitability and use growth in beginning invested capital $\left(\Delta \mathrm{IC}_{\mathrm{t}-1}\right)$ as a proxy for growth from investment.

However, the RI-based decomposition developed above is also subject to the following caveats. In this decomposition, we are estimating ex ante returns to new investments when we parse out the $\Delta \mathrm{IC}_{\mathrm{t}-1} * \mathrm{WACC}_{\mathrm{t}}$ term. In reality, new investments may earn a rate of return that is different from WACC. Further, growth in RI could itself arise either because of the increase in the profitability of existing assets or the high profitability of new investments being made. ${ }^{1}$ Because of this, we refrain from attaching any labels to these components of earnings growth, that is, we do not label $\Delta \mathrm{RI}_{\mathrm{t}}$ as growth from increased profitability or $\Delta \mathrm{IC}_{\mathrm{t}-1} * \mathrm{WACC}_{\mathrm{t}}$ as growth from investment. Instead, we attach descriptive labels, referring to $\Delta \mathrm{RI}_{\mathrm{t}}$ as earnings growth from growth in residual income and $\Delta \mathrm{IC}_{\mathrm{t}-1} * \mathrm{WACC}_{\mathrm{t}}$ as earnings growth from growth in invested capital.

\subsection{Using the decomposition in the returns-earnings specification}

We begin with the Easton and Harris (1991) specification, which expresses returns as a function of both the level of profitability $(\mathrm{NI})$ and growth in profitability $(\Delta \mathrm{NI})$. As $\Delta \mathrm{NI}_{\mathrm{t}}=\mathrm{NI}_{\mathrm{t}}-\mathrm{NI}_{\mathrm{t}-1}$, this equation can be restated as

\footnotetext{
${ }^{1}$ While decomposing the growth in RI further into a component driven by the increase in profitability of existing assets and a component driven by the high profitability of new investments is likely to be insightful, it is also potentially intractable without making even more ex ante assumptions regarding the profitability of existing assets and new investments. Untabulated results however indicate that growth in RI is positively associated with increase in asset turnover and profit margins and negatively associated with new investment.
} 


$$
\operatorname{RETM}_{\mathrm{t}}=\alpha_{0}+\beta_{1} \mathrm{NI}_{\mathrm{t}-1}+\beta_{2} \Delta \mathrm{NI}_{\mathrm{t}}+\varepsilon .
$$

This allows for easier interpretation of the coefficients, as $\mathrm{NI}_{\mathrm{t}-1}$ refers to past information and $\Delta \mathrm{NI}_{\mathrm{t}}$ refers to contemporaneous information. We substitute for the components of $\Delta \mathrm{NI}_{\mathrm{t}}$ from Eq. 6 to give the following specification.

$$
\begin{aligned}
\operatorname{RETM}_{\mathrm{t}}= & \alpha_{0}+\gamma_{1} * \mathrm{NI}_{\mathrm{t}-1}+\gamma_{2} \Delta \mathrm{RI}_{\mathrm{t}}+\gamma_{3}\left(\Delta \mathrm{IC}_{\mathrm{t}-1} * \mathrm{WACC}_{\mathrm{t}}\right) \\
& +\gamma_{4}\left(\Delta \mathrm{INT}_{\mathrm{t}} *(1-\mathrm{t})\right)+\gamma_{5}\left(\mathrm{IC}_{\mathrm{t}-2} * \Delta \mathrm{WACC}_{\mathrm{t}}\right)+\varepsilon .
\end{aligned}
$$

Consistent with our interpretation of the terms in Eq. 6, we interpret the coefficients from this regression as measures of how the stock market responds to earnings growth from the different components. For our decomposition to add value, it is necessary that the explanatory power of the regression for Eq. 8 exceeds that of the regression for Eq. 7.

\section{Sample selection and descriptive statistics}

\subsection{Sample selection}

We conduct our tests using a sample covering the period from 1975 through 2008. We rely entirely on publicly available information from two databases, the Compustat annual file and CRSP monthly returns file.

Table 1 outlines our sample selection procedure. We start from the Compustat annual file, with all firm-years from 1975 through 2008 with valid information needed to compute RI. Specifically, we require net income before extraordinary items (NIB), total assets (AT), stock price at fiscal year-end (PRCC_F), and shares outstanding (CSHO) needed to compute market capitalization, and total invested capital (sum of short term debt $\{$ DLC $\}$, long term debt $\{$ DLTT $\}$, minority interest $\{\mathrm{MIB}\}$ and total common equity $\{\mathrm{CEQ}\})$. To compute current and lagged RI, we assure the availability of lagged information for earnings and lagged and twicelagged information for invested capital. Further, we ensure that both contemporaneous and one-year-ahead information are available, and that we have enough returns (at least 24 prior months) to compute cost of equity and WACC, for all the firms in our sample. Finally, we eliminate financial services firms (2-digit SIC codes between 60 and 69) as the notion of invested capital is very different for these firms. We also eliminate utilities (2-digit SIC code 49) because firms in regulated industries are likely to have guaranteed rates of return on invested capital. Our final sample consists of 105,559 firm-years representing 11,979 distinct firms.

\subsection{Computation of RI and returns}

We compute RI as follows. NOPAT is income before extraordinary items (NIB) plus interest expense (XINT), adjusted for taxes. The tax rate is set to the prevailing statutory federal tax rate for each year, or zero for firms with net operating loss 
Table 1 Sample selection procedure

\begin{tabular}{|c|c|c|}
\hline & $\begin{array}{l}\text { Firm- } \\
\text { years }\end{array}$ & $\begin{array}{l}\text { Distinct } \\
\text { firms }\end{array}$ \\
\hline $\begin{array}{l}\text { Data on Compustat with information on net income, total assets, price, } \\
\text { shares outstanding, common equity, and debt in the } 1975-2008 \text { period }\end{array}$ & 238,367 & 24,822 \\
\hline $\begin{array}{l}\text { LESS firms with missing lagged information on net income and missing } \\
\text { lagged and twice-lagged information on invested capital }\end{array}$ & $\underline{44,002}$ & $\underline{3,574}$ \\
\hline Firms with adequate current and lagged financial information & 194,365 & 21,248 \\
\hline $\begin{array}{l}\text { LESS firms with deflators that are too small (lagged assets, market } \\
\text { capitalization, or invested capital under one million dollars) }\end{array}$ & $\underline{20,594}$ & $\underline{1,518}$ \\
\hline $\begin{array}{l}\text { Firms with adequate current and lagged financial information and } \\
\text { reasonable deflators }\end{array}$ & 173,771 & 19,730 \\
\hline LESS firms with missing current returns on CRSP & $\underline{33,235}$ & $\underline{4,324}$ \\
\hline $\begin{array}{l}\text { Firms with adequate current and lagged financial information, reasonable } \\
\text { deflators, and current returns }\end{array}$ & 140,536 & 15,406 \\
\hline LESS firms missing one-year-ahead returns on CRSP & $\underline{724}$ & $\underline{70}$ \\
\hline $\begin{array}{l}\text { Firms with adequate current and lagged financial information, reasonable } \\
\text { deflators, and current and future returns }\end{array}$ & 139,812 & 15,336 \\
\hline $\begin{array}{l}\text { LESS firms in utilities (2-digit SIC code 49) or financial services (2-digit } \\
\text { SIC codes between } 60 \text { and 69) }\end{array}$ & $\underline{34,253}$ & $\underline{3,357}$ \\
\hline Final sample & 105,559 & 11,979 \\
\hline
\end{tabular}

carry-forwards. ${ }^{2}$ RI is defined as NOPAT minus the WACC times lagged invested capital $($ DLC + DLTT + MIB + CEQ $) .^{3}$

Contemporaneous annual returns $\left(\mathrm{RETM}_{\mathrm{t}}\right)$ for a given firm are calculated by compounding CRSP monthly returns beginning 4 months after the beginning of the fiscal year and ending 12 months thereafter. We do this to allow enough time to ensure that annual financials are available. One-year-ahead returns $\left(\mathrm{RETM}_{\mathrm{t}+1}\right)$ are similarly calculated by starting the compounding period 4 months after the end of the fiscal year. We adjust the returns by subtracting the compounded return on the value-weighted index over the same period. ${ }^{4}$

\subsection{Descriptive statistics}

Panel A of Table 2 presents descriptive statistics for the sample firms. The large differences between the means and medians of our size variables (sales, assets, total

\footnotetext{
${ }^{2}$ Our results are not affected if we use the effective tax rate, defined as Income Tax Expense (Compustat TXT) divided by Income before Extraordinary Items and Tax (IB + TXT).

${ }^{3}$ WACC is calculated by (1) estimating a CAPM cost of equity using 60 past monthly returns, (2) inferring after-tax cost of debt from interest expense, total interest bearing debt, and the tax rate, and (3) using market value of equity and book value of total debt for their relative weights. We estimate $\beta$ using at least 24 months and up to 60 months of lagged returns. $\beta$ below 0.4 are set to 0.4 , while $\beta$ above 3 are set to 3 . If $\beta$ cannot be estimated, we use the contemporaneous median $\beta$ for firms with the same 2 -digit SIC code.

${ }^{4}$ We rerun all tests using fiscal year returns as well as 16 month returns (from beginning of prior year to 4 months after current fiscal year) to control for the fact that firms often make forecasts and preannouncements in the first quarter. The results are very similar and are not tabulated.
} 
Table 2 Sample descriptive statistics

Panel A: Descriptive statistics for sample firm-years $(N=105,559)$

\begin{tabular}{lccccc}
\hline & Mean & SD & Q1 & Median & Q3 \\
\hline Sales (\$millions) & $1,804.9$ & $9,196.5$ & 36.7 & 144.4 & 659.4 \\
Assets & $2,016.2$ & $12,088.6$ & 35.5 & 131.1 & 627.4 \\
Total beginning invested capital & $1,258.7$ & $7,686.5$ & 24.8 & 88.3 & 411.1 \\
Book value of equity & 762.4 & $4,182.3$ & 16.8 & 63.5 & 277.6 \\
Market value of equity & $1,607.4$ & $10,247.6$ & 24.0 & 100.6 & 510.1 \\
Book-to-market & 0.8 & 0.7 & 0.3 & 0.6 & 1.1 \\
Net income & 88.0 & 787.1 & -0.5 & 3.4 & 25.6 \\
Net income/lagged assets & $1.09 \%$ & $17.61 \%$ & $-1.10 \%$ & $4.40 \%$ & $9.08 \%$ \\
NOPAT & 114.9 & 868.3 & 0.3 & 5.2 & 34.3 \\
NOPAT/lagged assets & $2.75 \%$ & $17.01 \%$ & $0.78 \%$ & $6.18 \%$ & $10.48 \%$ \\
Cost of debt & $7.95 \%$ & $5.23 \%$ & $4.67 \%$ & $6.33 \%$ & $9.25 \%$ \\
Cost of equity & $13.00 \%$ & $4.59 \%$ & $9.58 \%$ & $12.35 \%$ & $15.60 \%$ \\
WACC & $11.72 \%$ & $4.12 \%$ & $8.65 \%$ & $11.07 \%$ & $13.93 \%$ \\
RI & 9.0 & 711.0 & -9.1 & -0.8 & 3.6 \\
RI/lagged assets & $-5.60 \%$ & $17.24 \%$ & $-8.26 \%$ & $-1.41 \%$ & $2.77 \%$ \\
\hline
\end{tabular}

Panel B: Industry distribution

\begin{tabular}{cllc}
\hline SIC Code & \multicolumn{1}{c}{ Description } & Firm-years & Sample \% \\
\hline 36 & Electronic and other electric equipment & 9,583 & 9.1 \\
73 & Business services & 9,407 & 8.9 \\
35 & Industrial machinery and equipment & 8,571 & 8.1 \\
28 & Chemicals and allied products & 8,532 & 8.1 \\
38 & Instruments and related products & 7,745 & 7.3 \\
13 & Oil and gas extraction & 4,785 & 4.5 \\
50 & Wholesale trade-durable goods & 3,340 & 3.2 \\
20 & Food and kindred products & 3,280 & 3.1 \\
37 & Transportation equipment & 3,012 & 2.9 \\
48 & Communication & 2,875 & 2.7 \\
34 & Fabricated metal products & 2,511 & 2.4 \\
33 & Primary metal industries & 2,198 & 2.1 \\
87 & Engineering and management services & 2,057 & 1.9 \\
& All other industries & 37,663 & 35.7 \\
\hline
\end{tabular}

Descriptive statistics use information from the Compustat Annual file as follows. Sales (SALE), assets (AT), invested capital (sum of debt in current liabilities (DLC), long-term debt (DLTT), minority interest (MIB) and total common equity (CEQ)), market value of equity (price (PRCC_F) times shares outstanding (CSHO)), and net income before extraordinary items (NIB). NOPAT is net income before extraordinary items plus interest expense (XINT) times (1-tax rate). Cost of debt is estimated as after-tax interest expense deflated by prior year's balance of short-term and long-term debt. Cost of equity is measured using CAPM betas estimated using 60 lagged months of returns (ensuring that at least 24 prior returns are available) and a market premium of 5\%. WACC is estimated from cost of equity and cost of debt, using book value of debt and market value of equity for weights. Residual income (RI) is NOPAT minus lagged invested capital * WACC. Panel B provides sample industry distribution 
invested capital, book and market value of equity) indicate skewness due to the presence of large firms. The considerable variation in the book-to-market ratio suggests the presence of both value (high BM) and growth (low BM) stocks in the sample. Interestingly, although the median net income and NOPAT are positive, the median RI is barely negative, indicating that fewer than half the firms in the sample cover their cost of capital.

Panel B of Table 2 presents the industry distribution. There is little evidence of industry clustering with no industry representing over $10 \%$ of the entire sample. In addition, untabulated results indicate that the number of observations per year varies from a low of 2,213 in 1979 to a high of 4,201 in 1998. No single year represents less than $2 \%$ or more than $4 \%$ of the sample, indicating a lack of time clustering.

Table 3 presents the descriptive statistics and correlations for the variables used in our analysis. The variables of interest are earnings growth $(\Delta \mathrm{NI})$ and it components: growth in RI $(\Delta \mathrm{RI})$, growth in invested capital $\left(\Delta \mathrm{IC}_{\mathrm{t}-1} * \mathrm{WACC}_{\mathrm{t}}\right)$, change in after-tax interest expense $\left(\Delta \operatorname{INT}_{\mathrm{t}} *(1-\mathrm{t})\right)$, and change in risk $\left(\mathrm{IC}_{\mathrm{t}-2} * \Delta \mathrm{WACC}_{\mathrm{t}}\right)$. All these variables are scaled by beginning market value of equity and winsorized at the 1 and $99 \%$ level using annual distributions. ${ }^{5}$

Panel A presents the means of all variables. By construction, the mean $\Delta \mathrm{NI}$ $(1.20 \%)$ equals $\Delta \mathrm{RI}(0.93 \%)$ plus $\Delta \mathrm{IC}_{\mathrm{t}-1} * \mathrm{WACC}_{\mathrm{t}}(0.47 \%)$, minus $\Delta \mathrm{INT}_{\mathrm{t}} *(1-\mathrm{t})$ $(0.21 \%)$ plus $\mathrm{IC}_{\mathrm{t}-2} * \Delta \mathrm{WACC}_{\mathrm{t}}(0.01 \%)$. The means of both contemporaneous and one-year-ahead returns are significantly greater than zero, as these are equally weighted means while the market index is value-weighted. Mean excess returns are close to zero if we use the equally weighted index.

Panel B presents means of annual cross-sectional correlations. Not surprisingly, $\Delta \mathrm{NI}$ and $\Delta \mathrm{RI}$ are highly correlated (0.97 Pearson, 0.91 Spearman). Interestingly, the correlation between $\Delta \mathrm{NI}$ and $\Delta \mathrm{IC}_{\mathrm{t}-1} * \mathrm{WACC}_{\mathrm{t}}$ is negative, indicating that large changes in income are seldom associated with growth because of investment. ${ }^{6}$ Both $\Delta \mathrm{NI}$ and $\Delta \mathrm{RI}$ show strong positive correlation with current returns $\left(\mathrm{RETM}_{\mathrm{t}}\right)$, with $\Delta \mathrm{NI}$ showing a marginally stronger correlation. Finally, $\Delta \mathrm{NI}$ and $\Delta \mathrm{RI}$ correlate positively, while $\Delta \mathrm{IC}_{\mathrm{t}-1} * \mathrm{WACC}_{\mathrm{t}}$ correlates negatively with future returns $\left(\right.$ RETM $\left._{\mathrm{t}+1}\right)$.

\section{Results}

\subsection{Components of earnings growth and contemporaneous returns}

We begin our analysis by examining the basic Easton and Harris (1991) specification (Eq. 7) by regressing contemporaneous market-adjusted stock returns

\footnotetext{
5 Deleting instead of winsorizing outliers yields similar results.

6 This could either indicate that payoffs to new investments occur with a lag or that capital is being raised without being deployed (i.e. uninvested cash). However, this negative correlation persists even when we net out financial assets in the computation of invested capital, suggesting that the latter explanation is improbable.
} 
Table 3 Descriptive statistics for analysis variables

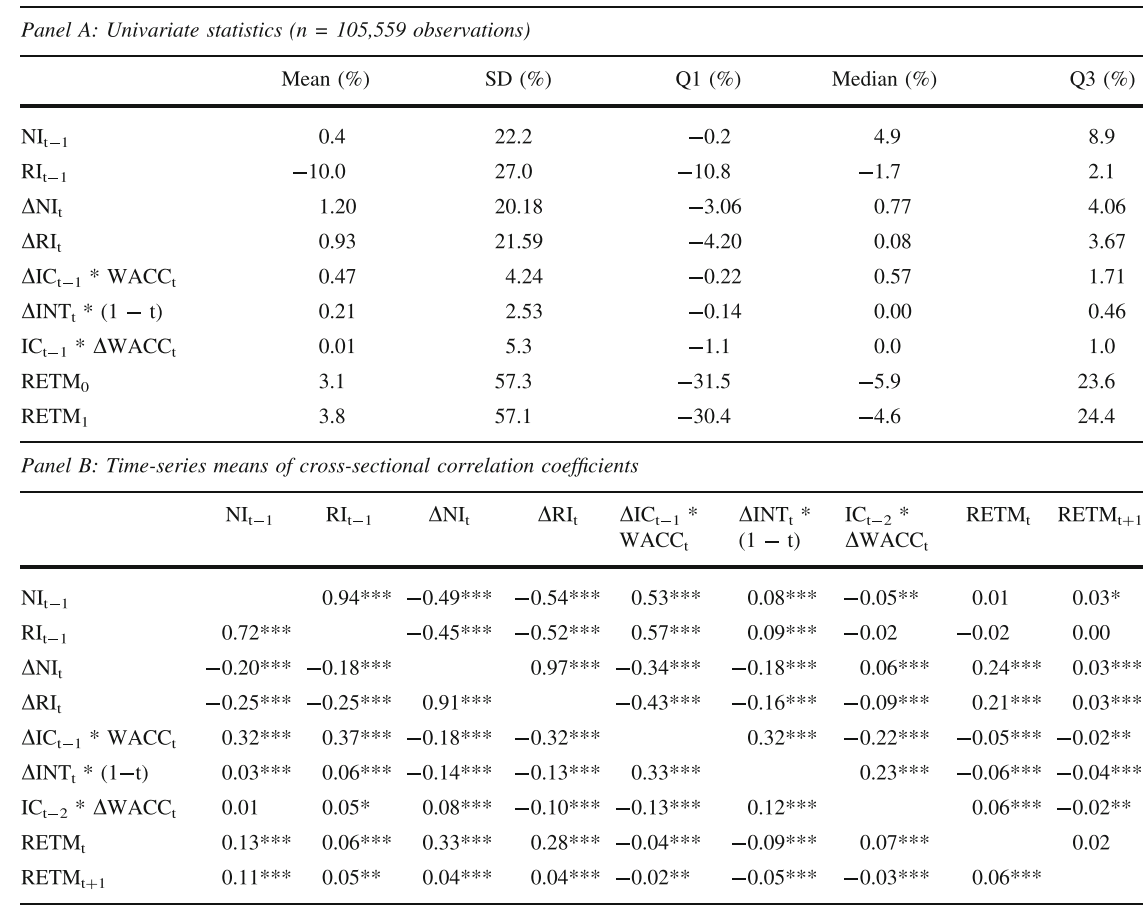

Figures above (below) diagonal are Pearson (Spearman) correlations

$\mathrm{NI}_{\mathrm{t}-1}$ is the lagged net income before extraordinary items (NIB). $\mathrm{RI}_{\mathrm{t}-1}$ is lagged residual income. $\Delta \mathrm{NI}_{\mathrm{t}}$ and $\Delta \mathrm{RI}_{\mathrm{t}}$ are the change in net income and residual income respectively. $\Delta \mathrm{IC}_{\mathrm{t}-1}$ is the lagged change in invested capital (\#37). WACC $\mathrm{t}_{\mathrm{t}}$ is the weighted average cost of capital. See header to Table 2 for detailed definitions. $\Delta \mathrm{INT}_{\mathrm{t}} *(1-\mathrm{t})$ is the change in after-tax interest expense (XINT). $\mathrm{IC}_{\mathrm{t}-1}$ is lagged invested capital. As discussed in Sect. 2.3, we decompose $\Delta \mathrm{NI}_{\mathrm{t}}=\Delta \mathrm{RI}_{\mathrm{t}}+\Delta \mathrm{IC}_{\mathrm{t}-1} * \mathrm{WACC}_{\mathrm{t}}-\Delta \mathrm{INT}_{\mathrm{t}} *(1-\mathrm{t})$ $+\mathrm{IC}_{\mathrm{t}-2} * \Delta \mathrm{WACC}_{\mathrm{t}}$ All variables above are scaled by lagged market value of equity $\left(\mathrm{PRCC}_{-} \mathrm{F} * \mathrm{CSHO}\right) . \mathrm{RETM}_{\mathrm{t}}$ and $\mathrm{RETM}_{\mathrm{t}+1}$ are, respectively, contemporaneous and one-year-ahead annual buy and hold returns, adjusted by subtracting value-weighted market returns compounded over the same time period. Returns are compounded starting 4 months after the prior fiscal year end for RETM and starting 4 months after the current fiscal year end for RETM $\mathrm{t}_{+1}$. Panel A presents the univariate statistics for the variables. Panel B presents the time series average of annual correlation coefficients among the components of earnings growth and stock returns. Significance levels of correlations are denoted by $* * *(1 \%) ; * *(5 \%) ; *(10 \%)$

$\left(\operatorname{RETM}_{\mathrm{t}}\right)$ on lagged earnings $\left(\mathrm{NI}_{\mathrm{t}-1}\right)$ and changes in earnings $\left(\Delta \mathrm{NI}_{\mathrm{t}}\right)$. We then analyze the regressions that substitute for $\Delta \mathrm{NI}_{\mathrm{t}}$ with the components of earnings growth. We conduct statistical tests using pooled regressions, with and without fixed effects, as well as annual regressions. Parameters for the annual regressions are time series averages from annual regressions using the Fama and Macbeth (1973) methodology with $t$-statistics adjusted for auto-correlation among the coefficients as in Bernard (1995). The results are presented in Table 4.

Panel A presents results for the basic Easton and Harris (1991) specification. The results are similar across all three specifications. The coefficient on the change in net 
Table 4 Regression of contemporaneous returns with components of income growth

\begin{tabular}{|c|c|c|c|}
\hline Variable & Pooled & Pooled with fixed effects & Annual \\
\hline Intercept & $\begin{array}{l}0.0203 \\
(11.21)\end{array}$ & & $\begin{array}{c}0.0165 \\
(0.76)\end{array}$ \\
\hline $\mathrm{NI}_{\mathrm{t}-1}$ & $\begin{array}{l}0.3160 \\
(22.40)\end{array}$ & $\begin{array}{l}0.3178 \\
(35.44)\end{array}$ & $\begin{array}{c}0.3934 \\
(8.34)\end{array}$ \\
\hline$\Delta \mathrm{NI}_{\mathrm{t}}$ & $\begin{array}{l}0.8096 \\
(56.47)\end{array}$ & $\begin{array}{l}0.7725 \\
(81.22)\end{array}$ & $\begin{array}{l}0.8312 \\
(24.14)\end{array}$ \\
\hline Adj. $R^{2}$ & $6.08 \%$ & $18.89 \%$ & $8.72 \%$ \\
\hline
\end{tabular}

Panel B: Regression of contemporaneous returns on lagged income and components of income growth $(N=105,559)$

\begin{tabular}{|c|c|c|c|}
\hline Variable & Pooled & Pooled with fixed effects & Annual \\
\hline Intercept & $\begin{array}{l}0.0240 \\
(12.83)\end{array}$ & & $\begin{array}{c}0.0147 \\
(0.70)\end{array}$ \\
\hline $\mathrm{NI}_{\mathrm{t}-1}$ & $\begin{array}{l}0.3619 \\
(23.58)\end{array}$ & $\begin{array}{l}0.3427 \\
(33.60)\end{array}$ & $\begin{array}{c}0.4212 \\
(9.33)\end{array}$ \\
\hline$\Delta \mathrm{RI}_{\mathrm{t}}$ & $\begin{array}{l}0.7815 \\
(53.43)\end{array}$ & $\begin{array}{l}0.7474 \\
(77.46)\end{array}$ & $\begin{array}{l}0.7991 \\
(24.73)\end{array}$ \\
\hline$\Delta \mathrm{IC}_{\mathrm{t}-1} * \mathrm{WACC}_{\mathrm{t}}$ & $\begin{array}{c}0.3140 \\
(4.23)\end{array}$ & $\begin{array}{c}0.5007 \\
(9.41)\end{array}$ & $\begin{array}{c}0.5674 \\
(2.45)\end{array}$ \\
\hline$\Delta \mathrm{INT}_{\mathrm{t}} *(1-\mathrm{t})$ & $\begin{array}{l}-1.4257 \\
(-13.75)\end{array}$ & $\begin{array}{l}-1.3667 \\
(-18.62)\end{array}$ & $\begin{array}{r}-1.4007 \\
(-8.49)\end{array}$ \\
\hline $\mathrm{IC}_{\mathrm{t}-2} * \Delta \mathrm{WACC}_{\mathrm{t}}$ & $\begin{array}{l}0.9874 \\
(19.30)\end{array}$ & $\begin{array}{l}1.2462 \\
(33.08)\end{array}$ & $\begin{array}{c}1.4589 \\
(7.57)\end{array}$ \\
\hline Adj. $\mathrm{R}^{2}$ & $6.32 \%$ & $19.54 \%$ & $9.49 \%$ \\
\hline
\end{tabular}

Panel C: Regression partitioned by size and profitability $(N=105,559)$

\begin{tabular}{lcccccc}
\hline Variable & $\begin{array}{c}\text { Small } \\
\text { firms }\end{array}$ & $\begin{array}{c}\text { Medium } \\
\text { firms }\end{array}$ & $\begin{array}{c}\text { Large } \\
\text { firms }\end{array}$ & $\begin{array}{c}\text { Low } \\
\text { profitability }\end{array}$ & $\begin{array}{c}\text { Medium } \\
\text { profitability }\end{array}$ & $\begin{array}{c}\text { High } \\
\text { profitability }\end{array}$ \\
\hline Intercept & 0.0711 & 0.0047 & -0.0225 & 0.0077 & 0.0186 & -0.0843 \\
& $(18.74)$ & $(1.39)$ & $(-6.14)$ & $(1.97)$ & $(1.97)$ & $(-16.16)$ \\
$\mathrm{NI}_{\mathrm{t}-1}$ & 0.3186 & 0.5590 & 0.6159 & 0.1901 & 0.7288 & 1.5023 \\
& $(15.69)$ & $(18.97)$ & $(14.07)$ & $(9.99)$ & $(9.99)$ & $(27.16)$ \\
$\Delta \mathrm{RI}_{\mathrm{t}}$ & 0.7227 & 0.9207 & 0.9226 & 0.6032 & 1.0199 & 1.3917 \\
& $(38.17)$ & $(33.55)$ & $(23.21)$ & $(34.02)$ & $(34.02)$ & $(30.78)$ \\
$\Delta \mathrm{IC}_{\mathrm{t}-1} * \mathrm{WACC}_{\mathrm{t}}$ & 0.3277 & 0.4687 & 0.4426 & 0.2723 & 0.2973 & 0.9034 \\
& $(2.96)$ & $(3.71)$ & $(3.59)$ & $(2.71)$ & $(2.71)$ & $(5.78)$ \\
$\Delta \mathrm{INT}_{\mathrm{t}} *(1-\mathrm{t})$ & -1.3492 & -1.6348 & -1.7274 & -1.0413 & -2.0416 & -2.0643 \\
& $(-9.36)$ & $(-9.39)$ & $(-8.93)$ & $(-7.24)$ & $(-7.24)$ & $(-8.36)$ \\
$\mathrm{IC}_{\mathrm{t}-2} * \Delta \mathrm{WACC}_{\mathrm{t}}$ & 0.8797 & 1.2078 & 1.1939 & 0.8769 & 1.1543 & 1.1996 \\
& $(12.37)$ & $(14.03)$ & $(13.33)$ & $(13.27)$ & $(13.27)$ & $(9.80)$ \\
$\mathrm{Adj}_{\mathrm{N} . \mathrm{R}}{ }^{2}$ & $7.00 \%$ & $6.82 \%$ & $4.93 \%$ & $5.98 \%$ & $8.83 \%$ & $8.82 \%$ \\
\hline
\end{tabular}


Table 4 continued

$\mathrm{NI}_{\mathrm{t}-1}$ is the lagged net income before extraordinary items (NIB). $\Delta \mathrm{RI}_{\mathrm{t}}$ is the change in residual income, computed as described in the header to Table 2. $\Delta \mathrm{IC}_{\mathrm{t}-1}$ is the lagged change in invested capital. WACC $\mathrm{W}_{\mathrm{t}}$ is the weighted average cost of capital, computed as described in Table $2 . \Delta \operatorname{INT}_{\mathrm{t}} *(1-\mathrm{t})$ is the change in after-tax interest expense (XINT). $\mathrm{IC}_{\mathrm{t}-1}$ is lagged invested capital. As discussed in Sect. 2.3, we decompose $\Delta \mathrm{NI}_{\mathrm{t}}=\Delta \mathrm{RI}_{\mathrm{t}}+\Delta \mathrm{IC}_{\mathrm{t}-1} * \mathrm{WACC}_{\mathrm{t}}-\Delta \mathrm{INT}_{\mathrm{t}} *(1-\mathrm{t})+\mathrm{IC}_{\mathrm{t}-2} * \Delta \mathrm{WACC}_{\mathrm{t}}$. All variables are scaled by lagged market value of equity ( $\left.\mathrm{PRCC} \_\mathrm{F} * \mathrm{CSHO}\right)$. The dependent variable, $\mathrm{RETM}_{\mathrm{t}}$, is the contemporaneous annual buy and hold returns adjusted by subtracting value-weighted market return compounded over the same time period. Returns are compounded starting 4 months after the prior fiscal year end. For Panels $\mathrm{A}$ and $\mathrm{B}$, regressions are run in pooled, pooled with fixed-effects and annual specifications. Pooled fixed effects regressions include effects for year and industry (2 digit SIC code). Figures in parentheses are $t$ statistics. $T$-statistics for the pooled regression include Newey and West (1987) corrections for clustering. Parameters for the annual regressions are time series averages of individual annual regressions using the Fama and Macbeth (1973) methodology, with $t$-statistics that control for auto-correlation as in Bernard (1995). The adjusted $R^{2}$ for the annual regressions is the time series average of the adjusted $R^{2}$ of the individual annual regressions. In Panel $A$, we regress $\mathrm{RETM}_{\mathrm{t}}$ on lagged income $\left(\mathrm{NI}_{t-1}\right)$ and current change in income $\left(\Delta \mathrm{NI}_{\mathrm{t}}\right)$. In Panel $\mathrm{B}$, we regress $\mathrm{RETM} \mathrm{t}_{\mathrm{t}}$ on lagged income $\left(\mathrm{NI}_{\mathrm{t}-1}\right)$ and components of change in income: $\Delta \mathrm{RI}_{\mathrm{t}}, \Delta \mathrm{IC}_{\mathrm{t}-1} * \mathrm{WACC}_{\mathrm{t}}, \Delta \mathrm{INT}_{\mathrm{t}} *(1-\mathrm{t})$ and $\mathrm{IC}_{\mathrm{t}-2} * \Delta \mathrm{WACC}_{\mathrm{t}}$. In Panel $\mathrm{C}$, we partition the sample into three groups on the basis of size (market capitalization) and profitability (return on invested capital) and rerun the pooled regressions in Panel B

income varies between 0.8096 for the pooled regression without fixed effects to 0.8312 for the annual regression. The adjusted $\mathrm{R}^{2}$ for the pooled regression without fixed effects is $6.08 \%$, increasing to $18.89 \%$ with industry and time fixed effects. The average adjusted $\mathrm{R}^{2}$ for the annual regressions is $8.72 \%$.

Panel $\mathrm{B}$ presents the regressions using our decomposition of earnings growth (Eq. 8). The coefficient $\gamma_{2}$ on $\Delta \mathrm{RI}_{\mathrm{t}}$ is 0.7815 (0.7474) for the pooled regression without (with) fixed effects, which increases to 0.7991 for the annual regression. The coefficient $\gamma_{3}$ on $\Delta \mathrm{IC}_{\mathrm{t}-1} * \mathrm{WACC}_{\mathrm{t}}$ is also significant in all specifications: 0.3140 (0.5007) for the pooled regressions without (with) fixed effects and 0.5674 for the annual regression. The significantly positive coefficient on $\Delta \mathrm{IC}_{\mathrm{t}-1} * \mathrm{WACC}_{\mathrm{t}}$ is consistent with the market expecting investments to generate a rate of return greater than the ex-ante assumption of investments earning WACC.

Hence, the market also appears to value earnings growth from growth in RI as well as earnings growth from growth in invested capital; however it does not place the same weight on each component. The coefficient on $\Delta \mathrm{RI}_{\mathrm{t}}$ is significantly greater than that on $\Delta \mathrm{IC}_{\mathrm{t}-1} * \mathrm{WACC}_{\mathrm{t}}$ in all specifications. Further, the coefficient $\gamma_{4}$ on $\Delta \mathrm{INT}_{\mathrm{t}} *(1-\mathrm{t})$ is significantly negative, and the coefficient $\gamma_{5}$ on $\mathrm{IC}_{\mathrm{t}-2} *$ $\Delta \mathrm{WACC}_{\mathrm{t}}$ is significantly positive, consistent with Eq. 6 .

The decomposition allows different weights for each component of earnings growth. If these weights had been restricted to be the same for each component, we would essentially be running the original Easton and Harris specification. The value of the RI-based decomposition is seen in the enhanced ability to explain the crosssection of returns. For the pooled regression without fixed effects, the adjusted $\mathrm{R}^{2}$ increases from $6.08 \%$ for the baseline model to $6.32 \%$ for the RI-based decomposition. Similar increases are seen for the other specifications as well. The 
Vuong (1989) test indicates that the increase in explanatory power between the models is strongly significant. ${ }^{7}$ In addition, the decomposition validates the importance of earnings growth from growth in RI, as the coefficient on $\Delta \mathrm{RI}_{t}$ is significantly greater than the coefficient on $\Delta \mathrm{IC}_{\mathrm{t}-1} * \mathrm{WACC}_{\mathrm{t}}$ in all specifications.

To better understand where the RI-based decomposition adds value, we rerun the analysis after partitioning our sample. In each year, we partition our sample into terciles on the basis of size (lagged market capitalization) and recent profitability (one period lagged return on invested capital). The results are presented in Panel C of Table 4. The first set of columns presents the regressions for the sample partitioned on the basis of size. In all three terciles, the coefficients on $\Delta \mathrm{RI}_{\mathrm{t}}$ and $\Delta \mathrm{IC}_{\mathrm{t}-1} * \mathrm{WACC}_{\mathrm{t}}$ continue to be strongly significant. Interestingly, both sets of coefficients are significantly lower for small firms. This suggests that contemporaneously the markets are less optimistic about earnings growth in smaller firms. The second set of columns present the regressions for the sample partitioned on the basis of recent profitability. Firms with high recent profitability have the most positive coefficient on both $\Delta \mathrm{RI}_{\mathrm{t}}$ and $\Delta \mathrm{IC}_{\mathrm{t}-1} * \mathrm{WACC}_{\mathrm{t}}$. For instance, the coefficient on $\Delta \mathrm{IC}_{\mathrm{t}-1} * \mathrm{WACC}_{\mathrm{t}}$ at 0.9034 is significantly greater than the coefficients for firms with low and medium profitability. This suggests that the market believes that investments made by firms with the greatest recent profitability are more likely to add value.

\subsection{Components of earnings growth and future earnings growth}

The regression results indicate that the capital market has a more favorable assessment of earnings growth when it is derived from growth in RI. To shed light why the stock market appears to favor growth in RI, we examine the relationship between current earnings growth and future earnings growth. Specifically, we assess whether earnings growth derived primarily from growth in RI is more persistent than earnings growth derived from growth in invested capital.

Dechow et al. (1998) show that earnings changes are negatively serially correlated, suggesting that the earnings growth is mean-reverting. Elgers and Lo (1994), however, show that negative earnings changes tend to reverse more in the next period than positive earnings changes. Ghosh et al. (2005) combine these insights in the following model to analyze the persistence of earnings growth. We use this as our baseline model.

$$
\begin{aligned}
\Delta \mathrm{NI}_{\mathrm{t}+1}= & \alpha_{0}+\alpha_{1} * \mathrm{NEG}+\alpha_{2} * \mathrm{POS}+\beta_{1} * \Delta \mathrm{NI}_{\mathrm{t}} * \mathrm{NEG} \\
& +\beta_{2} * \Delta \mathrm{NI}_{\mathrm{t}} * \mathrm{POS}+\varepsilon,
\end{aligned}
$$

where $\Delta \mathrm{NI}$ is change in earnings in the subscripted period, NEG is an indicator variable that takes the value 1 when current earnings growth is negative, and 0 otherwise, and POS takes value 1 when current earnings growth is positive and 0 otherwise.

\footnotetext{
${ }^{7}$ The $p$ value for the Vuong (1989) test for the difference in adjusted $\mathrm{R}^{2}$ is 0.0000 for the pooled regressions, both with and without fixed effects. For the annual regressions, the $p$ value is less than 0.10 in 29 out of 34 years.
} 
Next we expand Eq. 9 as follows: We define a variable called $\Delta$ RI_PROP, which equals the ratio of growth in RI to growth in NI (i.e. $\Delta \mathrm{RI}_{\mathrm{t}} / \Delta \mathrm{NI}_{\mathrm{t}}$ ). Similarly, we define INV_PROP as the ratio of earnings growth from growth in invested capital (i.e. $\left.\Delta \mathrm{IC}_{\mathrm{t}-1} * \mathrm{WACC}_{\mathrm{t}} / \Delta \mathrm{NI}_{\mathrm{t}}\right)$. $\Delta \mathrm{RI} \_\mathrm{PROP}$ and INV_PROP are set to zero for firms with negative earnings growth. We interact $\Delta$ RI_PROP and INV_PROP with $\Delta \mathrm{NI}_{\mathrm{t}} *$ POS to test whether the persistence of positive earnings growth differs based on the source of earnings growth. The model we use is

$$
\begin{aligned}
\Delta \mathrm{NI}_{\mathrm{t}+1}= & \alpha_{0}+\alpha_{1} * \mathrm{NEG}+\alpha_{2} * \mathrm{POS}+\beta_{1} * \Delta \mathrm{NI}_{\mathrm{t}} * \mathrm{NEG}+\beta_{2} * \Delta \mathrm{NI}_{\mathrm{t}} * \mathrm{POS} \\
& +\beta_{3} * \Delta \mathrm{RI} \_\mathrm{PROP}+\beta_{4} * \mathrm{INV} \_\mathrm{PROP}+\beta_{5} * \Delta \mathrm{NI}_{\mathrm{t}} * \mathrm{POS} * \Delta \mathrm{RI} \_\mathrm{PROP} \\
& +\beta_{6} * \Delta \mathrm{NI} \mathrm{t}_{\mathrm{t}} * \mathrm{POS} * \mathrm{INV} \_\mathrm{PROP}+\varepsilon .
\end{aligned}
$$

In the above models, $\beta_{1}$ and $\beta_{2}$ represent the persistence of negative and positive earnings growth, respectively. Prior research suggests that $\beta_{1}$ should be strongly negative as negative earnings growth is strongly mean reverting. Further, $\beta_{2}$ then should either be less negative than $\beta_{1}$ or even be positive, (i.e. positive earnings growth is more likely to persist than negative earnings growth). Finally, if future earnings are consistent with the contemporaneous market reaction to the components of earnings growth, we would expect $\beta_{5}$ to be positive and $\beta_{6}$ to be negative, i.e. positive earnings growth is more persistent when derived primarily from growth in RI and less persistent when derived primarily from growth in invested capital. The above regressions are run using the same specifications as earlier-pooled, pooled with fixed effects for time and industry, and annual.

The results are presented in Table 5. The first three columns present regressions for the baseline model. Consistent with prior research, the coefficient on $\Delta \mathrm{NI}_{\mathrm{t}} * \mathrm{NEG}$ is strongly negative in all specifications, indicating that negative earnings growth is strongly mean reverting. Further, the coefficient on $\Delta \mathrm{NI}_{\mathrm{t}} * \mathrm{POS}$ is significantly positive in all specifications, indicating that positive earnings growth does, on average, persist. The final three columns include the interactions for $\triangle$ RI_PROP and INV_PROP. As expected, the coefficient on the interaction of $\Delta \mathrm{NI}_{\mathrm{t}} *$ POS with $\triangle \mathrm{RI} \_\mathrm{PROP}$ is strongly significant and positive in all three specifications. This lends support for the conjecture that earnings growth derived primarily from growth in RI is more likely to be persistent. Further, the coefficient on the interaction of $\Delta \mathrm{NI}_{\mathrm{t}} *$ POS with INV_PROP is strongly significant and negative in all three specifications, suggesting that earnings growth derived from growth in invested capital tends to reverse. Interestingly, in the last 3 columns of Table 5, the coefficient on $\Delta \mathrm{NI}_{\mathrm{t}} * \mathrm{POS}$, which was formerly significantly positive (in the first 3 columns), is now significantly negative. This indicates that earnings growth, bereft of growth in RI, does not persist but reverses.

The analysis of earnings persistence is consistent with the contemporaneous return results discussed earlier. It suggests that growth in residual income is significantly associated with future earnings growth, which is valuable to shareholders. On the other hand, earnings growth derived from growth in investment does not persist and reverses in the future. These results lend support for the use of growth in RI as an appropriate measure of growth in profitability, as it accounts for the opportunity cost of funds. This is consistent with arguments made by accounting scholars such as Anthony (1973) enumerating the shortcomings of 
Table 5 Relation between persistence of earnings growth and components of earnings growth

\begin{tabular}{|c|c|c|c|c|c|c|}
\hline Variable & Pooled & $\begin{array}{l}\text { Pooled } \\
\text { with fixed } \\
\text { effects }\end{array}$ & Annual & Pooled & $\begin{array}{l}\text { Pooled } \\
\text { with fixed } \\
\text { effects }\end{array}$ & Annual \\
\hline Intercept & $\begin{array}{c}-0.0460 \\
(-1.26)\end{array}$ & & $\begin{array}{l}-0.0237 \\
(-1.42)\end{array}$ & $\begin{array}{c}-0.0460 \\
(-1.26)\end{array}$ & & $\begin{array}{l}-0.0194 \\
(-1.15)\end{array}$ \\
\hline NEG & $\begin{array}{c}0.0070 \\
(0.19)\end{array}$ & $\begin{array}{c}0.0095 \\
(0.26)\end{array}$ & $\begin{array}{c}-0.0149 \\
(-0.88)\end{array}$ & $\begin{array}{c}0.0070 \\
(0.19)\end{array}$ & $\begin{array}{c}0.0090 \\
(0.25)\end{array}$ & $\begin{array}{l}-0.0191 \\
(-1.12)\end{array}$ \\
\hline POS & $\begin{array}{l}0.0404 \\
(1.10)\end{array}$ & $\begin{array}{l}0.0407 \\
(1.11)\end{array}$ & $\begin{array}{l}0.0200 \\
(1.23)\end{array}$ & $\begin{array}{c}0.0480 \\
(1.31)\end{array}$ & $\begin{array}{c}0.0472 \\
(1.30)\end{array}$ & $\begin{array}{c}0.0232 \\
(1.41)\end{array}$ \\
\hline$\Delta \mathrm{NI}_{\mathrm{t}} * \mathrm{NEG}$ & $\begin{array}{c}-0.8635 \\
(-129.13)\end{array}$ & $\begin{array}{c}-0.8594 \\
(-127.76)\end{array}$ & $\begin{array}{l}-0.8480 \\
(-24.80)\end{array}$ & $\begin{array}{c}-0.8635 \\
(-129.52)\end{array}$ & $\begin{array}{c}-0.8592 \\
(-128.07)\end{array}$ & $\begin{array}{l}-0.8480 \\
(-24.8)\end{array}$ \\
\hline$\Delta \mathrm{NI}_{\mathrm{t}} * \mathrm{POS}$ & $\begin{array}{l}0.0310 \\
(7.58)\end{array}$ & $\begin{array}{c}0.0166 \\
(4.01)\end{array}$ & $\begin{array}{l}0.0181 \\
(1.74)\end{array}$ & $\begin{array}{c}-0.1742 \\
(-9.40)\end{array}$ & $\begin{array}{l}-0.1754 \\
(-9.19)\end{array}$ & $\begin{array}{l}-0.2123 \\
(-5.64)\end{array}$ \\
\hline$\triangle$ RI_PROP & & & & $\begin{array}{c}-0.0006 \\
(-1.39)\end{array}$ & $\begin{array}{c}-0.0010 \\
(-2.17)\end{array}$ & $\begin{array}{l}-0.0008 \\
(-1.76)\end{array}$ \\
\hline INV_PROP & & & & $\begin{array}{l}-0.0006 \\
(-1.24)\end{array}$ & $\begin{array}{l}-0.0003 \\
(-0.65)\end{array}$ & $\begin{array}{l}-0.0008 \\
(-1.59)\end{array}$ \\
\hline$\Delta \mathrm{NI}_{\mathrm{t}} * \mathrm{POS} * \Delta \mathrm{RI} \_\mathrm{PROP}$ & & & & $\begin{array}{l}0.1415 \\
(7.98)\end{array}$ & $\begin{array}{c}0.1309 \\
(7.16)\end{array}$ & $\begin{array}{c}0.1449 \\
(3.53)\end{array}$ \\
\hline$\Delta \mathrm{NI}_{\mathrm{t}} * \mathrm{POS} * \mathrm{INV} \_\mathrm{PROP}$ & & & & $\begin{array}{l}-0.3996 \\
(-16.48)\end{array}$ & $\begin{array}{l}-0.3997 \\
(-16.26)\end{array}$ & $\begin{array}{l}-0.4289 \\
(-6.03)\end{array}$ \\
\hline Adj. $R^{2}$ & $15.8 \%$ & $18.4 \%$ & $16.0 \%$ & $16.3 \%$ & $18.5 \%$ & $18.9 \%$ \\
\hline
\end{tabular}

The dependent variable is the future change in earnings $\left(\Delta \mathrm{NI}_{\mathrm{t}+1}\right)$ while the main independent variable is the current change in earnings $\left(\Delta \mathrm{NI}_{\mathrm{t}}\right)$, computed from net income before extraordinary items (NIB) and scaled by the corresponding beginning market value of equity (PRCC_F * CSHO). NEG is an indicator variable that equals 1 if $\Delta \mathrm{NI}_{\mathrm{t}}<0$ and 0 otherwise. POS is an indicator variable that equals 1 if $\Delta \mathrm{NI}_{\mathrm{t}}>0$ and 0 otherwise. $\Delta$ RI_PROP is defined as the ratio of $\Delta \mathrm{RI}_{\mathrm{t}}$ to $\Delta \mathrm{NI}_{\mathrm{t}}$. INV_PROP is defined as the ratio of $\Delta \mathrm{IC}_{\mathrm{t}-1} * \mathrm{WACC}_{\mathrm{t}}$ to $\Delta \mathrm{NI}_{\mathrm{t}}$. See header to Table 2 for computations of $\Delta \mathrm{RI}_{\mathrm{t}}$ and $\Delta \mathrm{IC}_{\mathrm{t}-1} * \mathrm{WACC}_{\mathrm{t}}$. $\triangle$ RI_PROP and INV_PROP are only computed when $\Delta \mathrm{NI}_{\mathrm{t}}>0$ and is set to zero for all other observations. Regressions are run in pooled specifications, with and without fixed effects, as well as annually. Pooled fixed-effects regressions include effects for year and industry (2-digit SIC code). Figures in parentheses are $t$-statistics. $T$-statistics for the pooled regression include Newey and West (1987) corrections for clustering. Parameters for the annual regressions are time-series averages of individual annual regressions using the Fama and Macbeth (1973) methodology, with $t$-statistics that control for auto-correlation as in Bernard (1995). The adjusted $\mathrm{R}^{2}$ for the annual regressions is the time-series average of the adjusted $\mathrm{R}^{2}$ of the individual annual regressions. The number of observations for all regressions is 97,039 across all years

earnings-based measures of profitability and advocating the use of residual income as an alternative measure of profitability.

\subsection{Components of earnings growth and future returns}

The results thus far indicate that both $\Delta \mathrm{RI}_{\mathrm{t}}$ and $\Delta \mathrm{IC}_{\mathrm{t}-1} * \mathrm{WACC}_{\mathrm{t}}$ are positively associated with contemporaneous returns. However, the analysis of the persistence of earnings growth suggests that the growth associated with $\Delta \mathrm{RI}_{\mathrm{t}}$ persists while the growth associated with $\Delta \mathrm{IC}_{\mathrm{t}-1} * \mathrm{WACC}_{\mathrm{t}}$ reverses. Prior research has shown that 
markets' contemporaneous reaction is often incorrect, as markets underreact to certain information (e.g., the post-earnings announcement drift demonstrated in Bernard and Thomas 1989) or overreact to other information (e.g. naive extrapolation of accruals as shown in Sloan 1996). To examine this issue further, we study the relationship between the components of earnings growth and future returns.

We modify the Easton and Harris (1991) specification by using one-year-ahead returns as the dependent variable. We regress one-year-ahead market-adjusted stock returns $\left(\mathrm{RETM}_{\mathrm{t}+1}\right)$ on lagged earnings $\left(\mathrm{NI}_{\mathrm{t}-1}\right)$ and changes in earnings $\left(\Delta \mathrm{NI}_{\mathrm{t}}\right)$ using the following specification:

$$
\operatorname{RETM}_{\mathrm{t}+1}=\alpha_{0}+\beta_{1} \mathrm{NI}_{\mathrm{t}-1}+\beta_{2} \Delta \mathrm{NI}_{\mathrm{t}}+\varepsilon .
$$

We also examine the relationship between the components of change in net income and future returns using the specification:

$$
\begin{aligned}
\operatorname{RETM}_{\mathrm{t}+1}= & \alpha_{0}+\delta_{1} * \mathrm{NI}_{\mathrm{t}-1}+\delta_{2} \Delta \mathrm{RI}_{\mathrm{t}}+\delta_{3}\left(\Delta \mathrm{IC}_{\mathrm{t}-1} * \mathrm{WACC}_{\mathrm{t}}\right) \\
& +\delta_{4}\left(\Delta \mathrm{INT}_{\mathrm{t}} *(1-\mathrm{t})\right)+\delta_{5}\left(\mathrm{IC}_{\mathrm{t}-2} * \Delta \mathrm{WACC}_{\mathrm{t}}\right)+\varepsilon .
\end{aligned}
$$

We interpret the coefficients from this regression as measures of how the stock market reinterprets its initial reaction to the components of earnings growth. For example, if any of the coefficients are positive, it implies that the market underreacted contemporaneously, leading to a drift in the future. However, if the coefficients are negative, it implies that the market overreacted contemporaneously, leading to a future reversal.

The results are presented in Table 6. Panel A presents the parameter estimates of Eq. 11 above. Consistent with the well-documented earnings drift literature, the coefficient on change in earnings $\left(\Delta \mathrm{NI}_{\mathrm{t}}\right)$ is significantly positive. Panel $\mathrm{B}$ of Table 6 presents the parameter estimates of Eq. 12 above. The future return results corroborate the results related to the persistence of earnings growth. The coefficient $\delta_{2}$ on $\Delta \mathrm{RI}$ is significant and positive in all specifications. This indicates that the market only partially impounds the increased persistence of earnings growth from growth in RI, (i.e., there is a drift with respect to change in RI). In contrast, the coefficient $\delta_{3}$ on $\Delta \mathrm{IC}_{\mathrm{t}-1} * \mathrm{WACC}_{\mathrm{t}}$ is significant and negative in all specifications. This is consistent with the market reversing its initial favorable assessment of earnings growth from growth in invested capital as it realizes that such earnings growth does not persist and instead reverses.

The positive relationship between future returns and earnings growth from growth in RI provides additional support for the contention in Anthony (1973) that growth in RI is a crucial metric of financial performance. The negative relationship between future returns and earnings growth from growth in invested capital, on the other hand, corroborates prior research that documents negative returns in the aftermath of investments such as mergers and acquisitions (Roll 1986; Harding and Yale 2002; Bower 2001) and capital expenditure (Titman et al. 2004). Finally, the adjusted $\mathrm{R}^{2}$ for all the regressions using the decomposition are significantly greater than the corresponding regression using only the change in earnings. ${ }^{8}$ Thus, the RI-based decomposition of earnings growth explains a larger cross section of current as well as future returns.

\footnotetext{
8 The $p$ value for the Vuong (1989) test for difference in adjusted $\mathrm{R}^{2}$ is 0.0000 for pooled regression both with and without fixed effects. For annual regressions, the $p$ value is $<0.10$ in 27 out of 34 years.
} 
Table 6 Regression of one-year-ahead returns with components of income growth

\begin{tabular}{|c|c|c|c|}
\hline \multicolumn{4}{|c|}{ Panel A: Regression of one-year-ahead returns on lagged income and income growth $(N=105,559)$} \\
\hline Variable & Pooled & Pooled with fixed effects & Annual \\
\hline \multirow[t]{2}{*}{ Intercept } & 0.0362 & & 0.0323 \\
\hline & $(19.34)$ & & $(1.34)$ \\
\hline \multirow[t]{2}{*}{$\mathrm{NI}_{\mathrm{t}-1}$} & 0.0877 & 0.0706 & 0.1076 \\
\hline & $(7.15)$ & $(7.63)$ & $(1.96)$ \\
\hline \multirow[t]{2}{*}{$\Delta \mathrm{NI}_{\mathrm{t}}$} & 0.1300 & 0.1040 & 0.1302 \\
\hline & (9.93) & (10.59) & $(2.94)$ \\
\hline Adj. $\mathrm{R}^{2}$ & $0.17 \%$ & $13.02 \%$ & $1.49 \%$ \\
\hline
\end{tabular}

Panel B: Regression of one-year-ahead returns on lagged income and components of income growth $(N=105,559)$

\begin{tabular}{lccc}
\hline Variable & Pooled & Pooled with fixed effects & Annual \\
\hline Intercept & 0.0394 & & 0.0299 \\
& $(20.46)$ & & $(1.25)$ \\
$\mathrm{NI}_{\mathrm{t}-1}$ & 0.1214 & 0.1040 & 0.1349 \\
& $(8.81)$ & $(9.87)$ & $(2.16)$ \\
$\Delta \mathrm{RI}_{\mathrm{t}}$ & 0.1066 & 0.0876 & 0.1128 \\
& $(7.95)$ & $(8.79)$ & $(2.46)$ \\
$\Delta \mathrm{IC}_{\mathrm{t}-1} * \mathrm{WACC}_{\mathrm{t}}$ & -0.2309 & -0.2766 & -0.2190 \\
& $(-3.43)$ & $(-5.03)$ & $(-2.09)$ \\
$\Delta \mathrm{INT}_{\mathrm{t}} *(1-\mathrm{t})$ & -0.8061 & -0.5728 & -0.5324 \\
& $(-8.73)$ & $(-7.55)$ & $(-2.74)$ \\
$\mathrm{IC}_{\mathrm{t}-2} * \Delta \mathrm{WACC}_{\mathrm{t}}$ & 0.1587 & -0.1017 & -0.1262 \\
$\mathrm{Adj}^{2} \mathrm{R}^{2}$ & $(3.59)$ & $(-2.61)$ & $(-0.99)$ \\
\hline
\end{tabular}

Panel C: Regression partitioned by size and profitability $(N=105,559)$

\begin{tabular}{lcccccc}
\hline Variable & $\begin{array}{c}\text { Small } \\
\text { firms }\end{array}$ & $\begin{array}{c}\text { Medium } \\
\text { firms }\end{array}$ & $\begin{array}{c}\text { Large } \\
\text { firms }\end{array}$ & $\begin{array}{c}\text { Low } \\
\text { profitability }\end{array}$ & $\begin{array}{c}\text { Medium } \\
\text { profitability }\end{array}$ & $\begin{array}{c}\text { High } \\
\text { profitability }\end{array}$ \\
\hline Intercept & 0.0610 & 0.0338 & 0.0207 & 0.0362 & 0.0383 & -0.0196 \\
& $(15.91)$ & $(9.56)$ & $(6.17)$ & $(8.95)$ & $(7.18)$ & $(-3.87)$ \\
$\mathrm{NI}_{\mathrm{t}-1}$ & 0.1491 & 0.1361 & 0.1333 & 0.0827 & 0.2823 & 0.6625 \\
& $(8.39)$ & $(4.65)$ & $(3.79)$ & $(4.77)$ & $(5.16)$ & $(13.2)$ \\
$\Delta \mathrm{RI}_{\mathrm{t}}$ & 0.1297 & 0.0798 & 0.0654 & 0.1043 & 0.0563 & 0.1943 \\
& $(7.73)$ & $(2.92)$ & $(1.88)$ & $(6.34)$ & $(1.93)$ & $(4.97)$ \\
$\Delta \mathrm{IC}_{\mathrm{t}-1} * \mathrm{WACC}_{\mathrm{t}}$ & -0.2746 & -0.1848 & -0.1110 & -0.1272 & -0.2256 & -0.3122 \\
& $(-2.84)$ & $(-1.48)$ & $(-0.92)$ & $(-1.42)$ & $(-1.77)$ & $(-2.40)$ \\
$\Delta \mathrm{INT}_{\mathrm{t}} *(1-\mathrm{t})$ & -0.9049 & -0.6271 & -0.7059 & -0.7373 & -0.8791 & -0.9686 \\
& $(-7.25)$ & $(-3.68)$ & $(-3.62)$ & $(-5.99)$ & $(-5.10)$ & $(-3.94)$ \\
$\mathrm{IC}_{\mathrm{t}-2} * \Delta \mathrm{WACC}_{\mathrm{t}}$ & 0.1970 & 0.1471 & -0.0223 & 0.1906 & 0.0497 & 0.2374 \\
& $(3.28)$ & $(1.74)$ & $(-0.25)$ & $(3.35)$ & $(0.56)$ & $(2.08)$ \\
$\mathrm{Adj}_{\mathrm{N} . \mathrm{R}}{ }^{2}$ & $0.59 \%$ & $0.18 \%$ & $0.13 \%$ & $0.33 \%$ & $0.41 \%$ & $0.84 \%$ \\
\hline
\end{tabular}


Table 6 continued

$\mathrm{NI}_{\mathrm{t}-1}$ is the lagged net income before extraordinary items (NIB). $\Delta \mathrm{RI}_{\mathrm{t}}$ is the change in residual income, computed as described in the header to Table 2. $\Delta \mathrm{IC}_{\mathrm{t}-1}$ is the lagged change in invested capital. WACC $\mathrm{C}_{\mathrm{t}}$ is the weighted average cost of capital, computed as described in Table $2 . \Delta \operatorname{INT}_{\mathrm{t}} *(1-\mathrm{t})$ is the change in after-tax interest expense (XINT). $\mathrm{IC}_{\mathrm{t}-1}$ is lagged invested capital. As discussed in Sect. 2.3, we decompose $\Delta \mathrm{NI}_{\mathrm{t}}=\Delta \mathrm{RI}_{\mathrm{t}}+\Delta \mathrm{IC}_{\mathrm{t}-1} * \mathrm{WACC}_{\mathrm{t}}-\Delta \mathrm{INT}_{\mathrm{t}} *(1-\mathrm{t})+\mathrm{IC}_{\mathrm{t}-2} * \Delta \mathrm{WACC}_{\mathrm{t}}$. All variables are scaled by lagged market value of equity ( $\left.\mathrm{PRCC}_{-} \mathrm{F} * \mathrm{CSHO}\right)$. The dependent variable, $\mathrm{RETM}_{\mathrm{t}+1}$, is the one-yearahead annual buy and hold returns adjusted by subtracting value-weighted market return compounded over the same time period. Returns are compounded starting 4 months after the current fiscal year-end. For Panels A and B, regressions are run in pooled, pooled with fixed-effects and annual specifications. Pooled fixed-effects regressions include effects for year and industry (2-digit SIC code). Figures in parentheses are $t$-statistics. $T$-statistics for the pooled regression include Newey and West (1987) corrections for clustering. Parameters for the annual regressions are time-series averages of individual annual regressions using the Fama and Macbeth (1973) methodology, with $t$-statistics that control for auto-correlation as in Bernard (1995). The adjusted $R^{2}$ for the annual regressions is the time series average of the adjusted $R^{2}$ of the individual annual regressions. In Panel $\mathrm{A}$, we regress $\mathrm{RETM}_{\mathrm{t}}$ on lagged income $\left(\mathrm{NI}_{\mathrm{t}-1}\right)$ and current change in income $\left(\Delta \mathrm{NI}_{\mathrm{t}}\right)$. In Panel $\mathrm{B}$, we regress $\mathrm{RETM}_{\mathrm{t}+1}$ on lagged income $\left(\mathrm{NI}_{\mathrm{t}-1}\right)$ and components of change in income: $\Delta \mathrm{RI}_{\mathrm{t}}, \Delta \mathrm{IC}_{\mathrm{t}-1} * \mathrm{WACC}_{\mathrm{t}}, \Delta \mathrm{INT}_{\mathrm{t}} *(1-\mathrm{t})$ and $\mathrm{IC}_{\mathrm{t}-2} * \Delta \mathrm{WACC}_{\mathrm{t}}$. In Panel $\mathrm{C}$, we partition the sample into three groups on the basis of size (market capitalization) and profitability (return on invested capital) and rerun the pooled regressions in Panel B

Panel C of Table 6 reruns the specification of Panel B for subsamples partitioned on the basis of size and recent profitability. The first set of columns presents the regressions for the firms partitioned on the basis of size. The results are strongest in the tercile of small firms, with the greatest positive coefficient on $\Delta \mathrm{RI}_{\mathrm{t}}$ and the most negative coefficient on $\Delta \mathrm{IC}_{\mathrm{t}-1} * \mathrm{WACC}_{\mathrm{t}}$. This is consistent with the market being especially susceptible to mispricing the components of earnings growth for small firms. The coefficient on $\Delta \mathrm{RI}_{\mathrm{t}}$ is 0.1297 for small firms, as against 0.0798 for medium firms and 0.0654 for large firms. Similarly, the coefficient on $\Delta \mathrm{IC}_{\mathrm{t}-1} * \mathrm{WACC}_{\mathrm{t}}$ is -0.2746 for small firms, as against -0.1848 for medium firms and -0.1110 for large firms. These results suggest a behavioral explanation for our results-if small firms are less likely to be scrutinized by sophisticated investors then the value of their earnings growth is more likely to be misconstrued. ${ }^{9}$

We also partition our sample on the basis of recent profitability. Interestingly, we find that the negative relationship between $\Delta \mathrm{IC}_{\mathrm{t}-1} * \mathrm{WACC}_{\mathrm{t}}$ and future returns is strongest for the tercile with the greatest profitability. This provides an interesting contrast to the earlier result that the strongest positive relationship between $\Delta \mathrm{IC}_{\mathrm{t}-1} * \mathrm{WACC}_{\mathrm{t}}$ and contemporaneous returns is prevalent in firms with the highest recent profitability. One interpretation of these results is that the market believes that investments made by firms with high recent profitability are likely to add value. However, such investments do not generate as much value as the market thinks they will, which results in future reversals.

\subsection{Trading strategy based on the decomposition of earnings growth}

The results thus far suggest that the market does not contemporaneously understand the implications of earnings growth arising from different components. We now

\footnotetext{
${ }^{9}$ In untabulated analyses, we find similar patterns when we partition the sample on the basis of the extent of analyst following or institutional investment, consistent with such a behavioral explanation.
} 
document the economic magnitude of our results by analyzing whether one can combine the market's underreaction to $\Delta \mathrm{RI}_{\mathrm{t}}$ and overreaction to $\Delta \mathrm{IC}_{\mathrm{t}-1} * \mathrm{WACC}_{\mathrm{t}}$ to create a trading rule that generates significant hedge returns. We measure oneyear-ahead returns for firms in the same manner as for our regression analysis as buy-and-hold returns for a 1 year period starting 4 months after fiscal year end. We divide firms into annual deciles on the basis of either earnings growth $\left(\Delta \mathrm{NI}_{t}\right)$ or the two main components of earnings growth we have focused on, $\Delta \mathrm{RI}_{\mathrm{t}}$ and $\Delta \mathrm{IC}_{\mathrm{t}-1} * \mathrm{WACC}_{\mathrm{t}}$. We then examine the patterns in returns for each of these deciles. The results are presented in Panel A of Table 7.

As a reference, we first create a hedge strategy based on $\Delta \mathrm{NI}_{\mathrm{t}}$. A strategy that takes a long position in the decile with the greatest increase in net income and a short position in the decile with the greatest decline in net income generates an average annual excess return of 5.0\%. Further, in 25 out of the 34 years, the strategy produces positive excess returns. Next, we implement a hedge strategy long on firms with the largest $\Delta \mathrm{RI}_{\mathrm{t}}$ and short on the firms with lowest $\Delta \mathrm{RI}_{\mathrm{t}}$ and find higher average hedge returns of $5.5 \%$, also positive in 25 out of the 34 years. Finally, we implement a hedge strategy that goes short in firms with the greatest $\Delta \mathrm{IC}_{\mathrm{t}-1} * \mathrm{WACC}_{\mathrm{t}}$ and long in firms with the lowest $\Delta \mathrm{IC}_{\mathrm{t}-1} * \mathrm{WACC}_{\mathrm{t}}$ and document average hedge returns of $5.3 \%$, positive in 21 out of 34 years.

Given the strong inverse correlation between $\Delta \mathrm{RI}_{\mathrm{t}}$ and $\Delta \mathrm{IC}_{\mathrm{t}-1} * \mathrm{WACC}_{\mathrm{t}}$, it is unclear whether the hedge returns based $\Delta \mathrm{RI}_{\mathrm{t}}$ are subsumed by the hedge returns based on $\Delta \mathrm{IC}_{\mathrm{t}-1} * \mathrm{WACC}_{\mathrm{t}}$. To test this, we create a composite variable combining both these components. We convert both $\Delta \mathrm{RI}_{\mathrm{t}}$ and $\Delta \mathrm{IC}_{\mathrm{t}-1} * \mathrm{WACC}_{\mathrm{t}}$ into ranks annually, with ranks for $\Delta \mathrm{IC}_{\mathrm{t}-1} * \mathrm{WACC}_{\mathrm{t}}$ in inverse order. We add these ranks to create a composite measure, RI_GROW. RI_GROW combines a preference for earnings growth from growth in RI with the avoidance of earnings growth from growth in invested capital. A hedge strategy based on RI_GROW generates average annual excess returns of $8.8 \%$, with positive returns in 29 out of 34 years. This represents a significant improvement over the $5.5 \%$ generated based on $\Delta \mathrm{RI}_{\mathrm{t}}$ as well as the $5.3 \%$ generated based on $\Delta \mathrm{IC}_{\mathrm{t}-1} * \mathrm{WACC}_{\mathrm{t}}$. We interpret the success of this strategy as reflecting the market's eventual realization that it had undervalued $\Delta \mathrm{RI}_{\mathrm{t}}$ and overvalued $\Delta \mathrm{IC}_{\mathrm{t}-1} * \mathrm{WACC}_{\mathrm{t}}$. This also validates the earnings persistence results by showing that separating out earnings growth into a component likely to persist $\left(\Delta \mathrm{RI}_{\mathrm{t}}\right)$ and a component likely to reverse $\left(\Delta \mathrm{IC}_{\mathrm{t}-1} * \mathrm{WACC}_{\mathrm{t}}\right)$ generates economically meaningful returns.

To ensure our results are not driven by omitted risk, we control for risk factors using the Fama and French (1993) three-factor and four-factor models. We create calendar-time portfolios of firms based on the decile of RI_GROW and regress the twelve monthly returns to these portfolios in the year after portfolio formation on the market factor $\left(\mathrm{R}_{\mathrm{m}}-\mathrm{R}_{\mathrm{f}}\right.$ ), size factor (SMB), book-to-market factor (HML), and, for the four-factor model, momentum (UMD). ${ }^{10}$ The regression is run in time series

\footnotetext{
${ }^{10}$ Although there is debate about whether momentum is, indeed, a risk factor, we include it in our tests to ensure that the results are incremental to a momentum effect. This can also be viewed as a control for the post-earnings-announcement drift, which as Chordia and Shivakumar (2006) show, is strongly related to price momentum.
} 
by pooling the twelve future months for the 34 years. The intercept (alpha) represents the future monthly excess return for each decile.

The results are presented in Panel B of Table 7. The first set of columns present the results from the three-factor model regression. Firms in the lowest RI_GROW

Table 7 Returns to hedge strategies based on components of earnings growth

\begin{tabular}{|c|c|c|c|c|c|}
\hline Year & Decile size & $\begin{array}{c}\Delta \mathrm{NI}_{\mathrm{t}} \\
\text { deciles }\end{array}$ & $\begin{array}{c}\Delta \mathrm{RI}_{\mathrm{t}} \\
\text { deciles }\end{array}$ & $\begin{array}{l}\Delta \mathrm{IC}_{\mathrm{t}-1} * \mathrm{WACC}_{\mathrm{t}} \\
\text { deciles }\end{array}$ & $\begin{array}{c}\text { RI_GROW } \\
\text { deciles }\end{array}$ \\
\hline 1975 & 248 & $0.5 \%$ & $-1.7 \%$ & $-1.2 \%$ & $1.9 \%$ \\
\hline 1976 & 247 & $5.7 \%$ & $5.3 \%$ & $-0.3 \%$ & $3.8 \%$ \\
\hline 1977 & 237 & $11.1 \%$ & $12.4 \%$ & $2.9 \%$ & $6.9 \%$ \\
\hline 1978 & 229 & $10.9 \%$ & $11.7 \%$ & $2.0 \%$ & $7.1 \%$ \\
\hline 1979 & 221 & $16.1 \%$ & $12.9 \%$ & $7.1 \%$ & $1.0 \%$ \\
\hline 1980 & 226 & $10.9 \%$ & $10.2 \%$ & $9.7 \%$ & $11.8 \%$ \\
\hline 1981 & 236 & $19.5 \%$ & $21.4 \%$ & $7.4 \%$ & $-5.2 \%$ \\
\hline 1982 & 244 & $-1.1 \%$ & $4.6 \%$ & $4.6 \%$ & $18.9 \%$ \\
\hline 1983 & 264 & $13.4 \%$ & $14.9 \%$ & $7.1 \%$ & $17.3 \%$ \\
\hline 1984 & 258 & $9.5 \%$ & $8.7 \%$ & $-5.3 \%$ & $-2.8 \%$ \\
\hline 1985 & 273 & $2.9 \%$ & $3.6 \%$ & $14.3 \%$ & $9.8 \%$ \\
\hline 1986 & 272 & $-3.4 \%$ & $-0.6 \%$ & $-2.5 \%$ & $11.5 \%$ \\
\hline 1987 & 271 & $5.3 \%$ & $7.8 \%$ & $-8.5 \%$ & $8.3 \%$ \\
\hline 1988 & 279 & $15.3 \%$ & $12.6 \%$ & $9.8 \%$ & $8.4 \%$ \\
\hline 1989 & 290 & $9.8 \%$ & $11.3 \%$ & $15.1 \%$ & $25.5 \%$ \\
\hline 1990 & 285 & $6.7 \%$ & $6.7 \%$ & $-5.6 \%$ & $4.3 \%$ \\
\hline 1991 & 287 & $1.2 \%$ & $-1.6 \%$ & $-0.6 \%$ & $12.8 \%$ \\
\hline 1992 & 295 & $4.5 \%$ & $8.5 \%$ & $10.4 \%$ & $8.9 \%$ \\
\hline 1993 & 315 & $-3.4 \%$ & $-2.6 \%$ & $8.6 \%$ & $9.8 \%$ \\
\hline 1994 & 341 & $10.1 \%$ & $12.3 \%$ & $17.7 \%$ & $22.0 \%$ \\
\hline 1995 & 371 & $7.1 \%$ & $5.7 \%$ & $-0.7 \%$ & $-5.7 \%$ \\
\hline 1996 & 395 & $7.0 \%$ & $8.8 \%$ & $4.9 \%$ & $14.2 \%$ \\
\hline 1997 & 408 & $-2.2 \%$ & $-1.4 \%$ & $12.4 \%$ & $13.3 \%$ \\
\hline 1998 & 420 & $-3.7 \%$ & $-7.1 \%$ & $24.1 \%$ & $17.5 \%$ \\
\hline 1999 & 405 & $13.5 \%$ & $12.0 \%$ & $-9.2 \%$ & $7.4 \%$ \\
\hline 2000 & 384 & $-9.3 \%$ & $-4.8 \%$ & $-6.1 \%$ & $-0.7 \%$ \\
\hline 2001 & 383 & $7.2 \%$ & $6.7 \%$ & $13.0 \%$ & $17.7 \%$ \\
\hline 2002 & 384 & $-3.2 \%$ & $1.8 \%$ & $38.1 \%$ & $16.9 \%$ \\
\hline 2003 & 370 & $-6.8 \%$ & $-7.1 \%$ & $-12.7 \%$ & $1.2 \%$ \\
\hline 2004 & 359 & $19.6 \%$ & $19.9 \%$ & $7.8 \%$ & $15.6 \%$ \\
\hline 2005 & 348 & $2.0 \%$ & $2.8 \%$ & $-0.2 \%$ & $-1.6 \%$ \\
\hline 2006 & 341 & $11.1 \%$ & $8.5 \%$ & $-10.1 \%$ & $5.0 \%$ \\
\hline 2007 & 332 & $9.0 \%$ & $7.2 \%$ & $3.9 \%$ & $11.1 \%$ \\
\hline 2008 & 326 & $-26.7 \%$ & $-23.7 \%$ & $21.4 \%$ & $5.3 \%$ \\
\hline \multirow[t]{2}{*}{ Avg. } & 310 & $5.0 \%$ & $5.5 \%$ & $5.3 \%$ & $8.8 \%$ \\
\hline & & $(3.15)$ & $(3.70)$ & $(2.86)$ & $(5.64)$ \\
\hline Positive & & $25 / 34$ & $25 / 34$ & $21 / 34$ & $29 / 34$ \\
\hline
\end{tabular}


Table 7 continued

\begin{tabular}{|c|c|c|c|c|c|c|c|c|c|c|c|}
\hline \multirow[t]{2}{*}{ Decile } & \multicolumn{5}{|c|}{ 3-Factor model } & \multicolumn{6}{|c|}{ 4-Factor model } \\
\hline & $\alpha(\%)$ & $\begin{array}{l}\mathrm{R}_{\mathrm{m}}- \\
\mathrm{R}_{\mathrm{f}}\end{array}$ & SMB & HML & $\begin{array}{c}\text { Adj. } \mathrm{R}^{2} \\
(\%)\end{array}$ & $\alpha(\%)$ & $\begin{array}{l}\mathrm{R}_{\mathrm{m}}- \\
\mathrm{R}_{\mathrm{f}}\end{array}$ & SMB & HML & UMD & $\begin{array}{c}\text { Adj. } \mathrm{R}^{2} \\
(\%)\end{array}$ \\
\hline 1 & -0.36 & 1.12 & $\begin{array}{l}1.01 \\
(19.12)\end{array}$ & $\begin{array}{l}0.31 \\
(5.52)\end{array}$ & 80.0 & $\begin{array}{l}-0.12 \\
(-0.78)\end{array}$ & $\begin{array}{l}1.07 \\
(29.98)\end{array}$ & $\begin{array}{l}1.02 \\
(20.69)\end{array}$ & $\begin{array}{l}0.21 \\
(3.95)\end{array}$ & $\begin{array}{l}-0.24 \\
(-7.5)\end{array}$ & 82.3 \\
\hline 2 & $\begin{array}{l}-0.21 \\
(-1.66)\end{array}$ & $\begin{array}{l}1.11 \\
(37.37)\end{array}$ & $\begin{array}{l}0.9 \\
(21.4)\end{array}$ & $\begin{array}{l}0.27 \\
(5.9)\end{array}$ & 85.4 & $\begin{array}{l}0.03 \\
(0.29)\end{array}$ & $\begin{array}{l}1.05 \\
(39.25)\end{array}$ & $\begin{array}{l}0.92 \\
(24.66)\end{array}$ & $\begin{array}{l}0.17 \\
(4.06)\end{array}$ & $\begin{array}{l}-0.26 \\
(-10.64)\end{array}$ & 88.5 \\
\hline 3 & $\begin{array}{l}-0.05 \\
(-0.45)\end{array}$ & $\begin{array}{l}1.05 \\
(39.41)\end{array}$ & $\begin{array}{l}0.88 \\
(23.34)\end{array}$ & $\begin{array}{l}0.15 \\
(3.83)\end{array}$ & 87.3 & $\begin{array}{l}0.19 \\
(1.94)\end{array}$ & $\begin{array}{l}0.99 \\
(42.62)\end{array}$ & $\begin{array}{l}0.90 \\
(27.78)\end{array}$ & $\begin{array}{l}0.06 \\
(1.56)\end{array}$ & $\begin{array}{l}-0.26 \\
(-12.14)\end{array}$ & 90.6 \\
\hline 4 & $\begin{array}{l}0.01 \\
(0.08)\end{array}$ & $\begin{array}{l}1.06 \\
(46.59)\end{array}$ & $\begin{array}{l}0.81 \\
(25.06)\end{array}$ & $\begin{array}{l}0.18 \\
(5.11)\end{array}$ & 90.0 & $\begin{array}{l}0.20 \\
(2.33)\end{array}$ & $\begin{array}{l}1.01 \\
(49.66)\end{array}$ & $\begin{array}{l}0.82 \\
(28.95)\end{array}$ & $\begin{array}{l}0.1 \\
(3.11)\end{array}$ & $\begin{array}{l}-0.2 \\
(-10.91)\end{array}$ & 92.2 \\
\hline 5 & $\begin{array}{l}0.20 \\
(1.94)\end{array}$ & $\begin{array}{l}1.01 \\
(42.77)\end{array}$ & $\begin{array}{l}0.79 \\
(23.46)\end{array}$ & $\begin{array}{l}0.13 \\
(3.68)\end{array}$ & 88.6 & $\begin{array}{l}0.38 \\
(4.1)\end{array}$ & $\begin{array}{l}0.97 \\
(44.42)\end{array}$ & $\begin{array}{l}0.8 \\
(26.36)\end{array}$ & $\begin{array}{l}0.06 \\
(1.71)\end{array}$ & $\begin{array}{l}-0.19 \\
(-9.59)\end{array}$ & 90.7 \\
\hline 6 & $\begin{array}{l}0.25 \\
(2.66)\end{array}$ & $\begin{array}{l}1.01 \\
(46.8)\end{array}$ & $\begin{array}{l}0.78 \\
(25.46)\end{array}$ & $\begin{array}{l}0.21 \\
(6.49)\end{array}$ & 90.0 & $\begin{array}{l}0.37 \\
(4.13)\end{array}$ & $\begin{array}{l}0.98 \\
(46.92)\end{array}$ & $\begin{array}{l}0.79 \\
(27.11)\end{array}$ & $\begin{array}{l}0.16 \\
(5.08)\end{array}$ & $\begin{array}{l}-0.13 \\
(-6.82)\end{array}$ & 91.0 \\
\hline 7 & $\begin{array}{l}0.30 \\
(3.28)\end{array}$ & $\begin{array}{l}0.99 \\
(46.21)\end{array}$ & $\begin{array}{l}0.82 \\
(26.75)\end{array}$ & $\begin{array}{l}0.16 \\
(4.92)\end{array}$ & 90.2 & $\begin{array}{l}0.44 \\
(5.02)\end{array}$ & $\begin{array}{l}0.96 \\
(47.18)\end{array}$ & $\begin{array}{l}0.83 \\
(29.2)\end{array}$ & $\begin{array}{l}0.1 \\
(3.36)\end{array}$ & $\begin{array}{l}-0.15 \\
(-8.1)\end{array}$ & 91.6 \\
\hline 8 & $\begin{array}{l}0.30 \\
(3.24)\end{array}$ & $\begin{array}{l}0.99 \\
(46.39)\end{array}$ & $\begin{array}{l}0.82 \\
(27.07)\end{array}$ & $\begin{array}{l}0.15 \\
(4.61)\end{array}$ & 90.4 & $\begin{array}{l}0.44 \\
(5.03)\end{array}$ & $\begin{array}{l}0.96 \\
(47.18)\end{array}$ & $\begin{array}{l}0.83 \\
(29.39)\end{array}$ & $\begin{array}{l}0.09 \\
(2.97)\end{array}$ & $\begin{array}{l}-0.15 \\
(-7.98)\end{array}$ & 91.6 \\
\hline 9 & $\begin{array}{l}0.45 \\
(3.63)\end{array}$ & $\begin{array}{l}0.99 \\
(34.07)\end{array}$ & $\begin{array}{l}0.92 \\
(22.45)\end{array}$ & $\begin{array}{l}0.18 \\
(4.15)\end{array}$ & 84.4 & $\begin{array}{l}0.60 \\
(4.89)\end{array}$ & $\begin{array}{l}0.96 \\
(33.47)\end{array}$ & $\begin{array}{l}0.93 \\
(23.54)\end{array}$ & $\begin{array}{l}0.12 \\
(2.84)\end{array}$ & $\begin{array}{l}-0.15 \\
(-5.81)\end{array}$ & 85.5 \\
\hline 10 & $\begin{array}{l}0.54 \\
(3.65)\end{array}$ & $\begin{array}{l}1.01 \\
(29.09)\end{array}$ & $\begin{array}{l}1.04 \\
(21.12)\end{array}$ & $\begin{array}{l}0.27 \\
(5.18)\end{array}$ & 80.4 & $\begin{array}{l}0.74 \\
(5.11)\end{array}$ & $\begin{array}{l}0.97 \\
(28.55)\end{array}$ & $\begin{array}{l}1.06 \\
(22.39)\end{array}$ & $\begin{array}{l}0.19 \\
(3.75)\end{array}$ & $\begin{array}{l}-0.2 \\
(-6.46)\end{array}$ & 82.1 \\
\hline$(10-1)$ & $\begin{array}{l}0.90 \\
(4.15)\end{array}$ & & & & & $\begin{array}{l}0.86 \\
(4.1)\end{array}$ & & & & & \\
\hline
\end{tabular}

As discussed in Sect. 2.3, we decompose $\Delta \mathrm{NI}_{\mathrm{t}}=\Delta \mathrm{RI}_{\mathrm{t}}+\Delta \mathrm{IC}_{\mathrm{t}-1} * \mathrm{WACC}_{\mathrm{t}}-\Delta \mathrm{INT}_{\mathrm{t}} *$ $(1-\mathrm{t})+\mathrm{IC}_{\mathrm{t}-2} * \Delta \mathrm{WACC}$. See header to Tables 2 and 4 for detailed definitions. We combine $\Delta \mathrm{RI}_{\mathrm{t}}$ and $\Delta \mathrm{IC}_{\mathrm{t}-1} * \mathrm{WACC}_{\mathrm{t}}$ into a composite measure, RI_GROW, that incorporates a preference for earnings growth from growth in RI with an avoidance of earnings growth from growth in invested capital, as described in Sect. 4.4. In each year, we form equally weighted deciles on the basis of $\Delta \mathrm{NI}_{\mathrm{t}}, \Delta \mathrm{RI}_{\mathrm{t}}$, $\Delta \mathrm{IC}_{\mathrm{t}-1} * \mathrm{WACC}_{\mathrm{t}}$ and RI_GROW. The table below presents the annual hedge returns $\left(\mathrm{HRET}_{\mathrm{t}+1}\right)$ for $\mathrm{a}$ strategy of going long in firms in the highest deciles of $\Delta \mathrm{NI}_{\mathrm{t}}, \Delta \mathrm{RI}_{\mathrm{t}}$, and RI_GROW (lowest decile of $\Delta \mathrm{IC}_{\mathrm{t}-1} * \mathrm{WACC}_{\mathrm{t}}$ ) and going short in firms in the lowest deciles of $\Delta \mathrm{NI}_{\mathrm{t}}, \Delta \mathrm{RI}_{\mathrm{t}}$, and RI_GROW (highest decile of $\Delta \mathrm{IC}_{\mathrm{t}-1} * \mathrm{WACC}_{\mathrm{t}}$ ). Figures in parentheses are $t$-statistics, calculated from the distribution of annual hedge returns. Panel B presents results of calendar time-series regressions with the monthly return for deciles based on RI_GROW as the dependent variable, and the Fama and French (1993) risk factors as independent variables. The three-factor model uses the market factor $\left(R_{m}-R_{f}\right)$, size factor (SMB), bookto-market factor (HML). The 4-factor model also includes momentum (UMD). The regressions pool 34 years of monthly returns for each portfolio, with 404 observations for each regression (2008 has only 8 observations as return compounding starts in May 2009 and data is available only until Dec 2009). The intercepts (alpha) to these portfolios represent the monthly excess returns earned in the year following portfolio formation

decile earn a significant negative return of $-0.36 \%$, while firms in the highest RI_GROW decile earn a significant positive return of $0.54 \%$. The alphas increase monotonically from the lowest to the highest decile. The difference between the alphas of the extreme RI_GROW portfolios is $0.9 \%$, equivalent to an annualized difference of $11.3 \%$. The next set of columns present the results of the four-factor 
model. Although the lowest decile firms no longer show a significantly negative alpha, the difference in alphas between extreme portfolios is still significant at $0.86 \%$, equivalent to an annualized difference of $10.8 \%$.

To put our results in perspective, Titman et al. (2004) report spreads of $0.20-0.28 \%$ between extreme quintiles of firms based on capital expenditures. Correspondingly, if we run our tests using quintiles (alphas to deciles 9 and 10 minus alphas to deciles 1 and 2), we find alpha spreads of $0.65-0.75 \%$. Hence, our composite measure derived from the RI-based decomposition generates excess returns that are three times as large as those from a capital expenditure based strategy.

\subsection{Sensitivity analysis}

To ensure that our results are not driven by our research design choices, we run the following sensitivity tests. First, we replicate the regressions for contemporaneous and future returns by controlling for the effects of conservatism and growth, which can distort the growth in residual income. Second, we use alternate definitions of residual income for the regressions, focusing mainly on the measurement of cost of capital. Third, we modify our decomposition by relaxing the assumption that new investments earn the cost of capital. Fourth, we run additional tests to ensure that our hedge return results are incremental to other documented anomalies.

\subsubsection{The confounding effect of conservatism and growth}

Rajan et al. (2007) show that the growth in RI can be overstated for slow-growing conservative firms and understated for fast-growing conservative firms. This can cloud any interpretation that one attaches to growth in RI as generating value for shareholders. As a sensitivity test, we rerun the regressions for both current as well as future returns with controls for the interplay of accounting conservatism and growth.

We measure conservatism using the C-SCORE measure of Penman and Zhang (2002), who define C-SCORE as the sum of capitalized research and development, capitalized advertising expense, and the LIFO reserve scaled by net operating assets. ${ }^{11}$ We define a dummy variable CONS, which equals 1 if a firm's C-SCORE is greater than the contemporaneous industry median (on the basis of two-digit SIC

\footnotetext{
11 Consistent with Penman and Zhang (2002), we capitalize research and development (XRD) over a five-year amortization period and advertising expense (XAD) over a two-year amortization period, using the sum-of-years-digits method. If the data for R\&D or advertising are missing, we set them to zero. Instead of net operating assets, we use total assets (AT) as our deflator, as the information to calculate net operating assets is either unavailable or net operating assets are negative for over $10 \%$ of all firms.

12 The growth rate in invested capital is measured over a five-year horizon. If 5 years of data are not available, a firm is classified as neither fast or slow (i.e. both FAST and SLOW are set to zero).
} 
codes) and 0 otherwise. We also define a dummy variable called SLOW (FAST), which equals 1 if the firm's recent annualized growth rate in invested capital is less (greater) than its WACC, and 0 otherwise. ${ }^{12}$ In our analysis, we interact $\Delta \mathrm{RI}_{\mathrm{t}}$ with CONS*FAST and CONS*SLOW to control for the interplay of growth and conservatism.

Panel A of Table 8 presents the results for the model with the above interactions. The first set of columns present the regression for contemporaneous returns. Our basic result with respect to contemporaneous returns is unaltered as the coefficients on both $\Delta \mathrm{RI}_{\mathrm{t}}$ and $\Delta \mathrm{IC}_{\mathrm{t}-1} * \mathrm{WACC}_{\mathrm{t}}$ are significant and positive. The coefficient on $\Delta \mathrm{RI}_{\mathrm{t}} * \mathrm{CONS} * \mathrm{FAST}$ is a highly significant 0.3018 , consistent with the markets capitalizing growth in RI at a higher rate for fast growing conservative firms, where such growth is likely understated. The incremental coefficient on $\Delta \mathrm{RI}_{\mathrm{t}}{ }^{*} \mathrm{CONS}{ }^{*}$ SLOW is however insignificant. The next set of columns presents the regression for one-year-ahead returns. Controlling for conservatism does not impact our basic result as we continue to observe a positive drift with respect to $\Delta \mathrm{RI}_{\mathrm{t}}$ and a reversal with respect to $\Delta \mathrm{IC}_{\mathrm{t}-1} * \mathrm{WACC}_{\mathrm{t}}$. The incremental coefficients on the interactions with respect to conservatism and growth are however insignificant. To summarize, the relationship between components of income growth and both contemporaneous and future returns is unlikely to be driven by errors in the estimation of growth in residual income caused by the interplay of conservatism and growth.

\subsubsection{Alternate specifications for RI}

The computation of RI, the focal point of our decomposition, is crucial to our analysis. In practice, RI is measured using a variety of different methodologies. While analyzing financial statements, one can net out financial assets from debt in the computation of invested capital. In addition, there is considerable variation in how cost of capital is measured. Different measures of cost of capital will lead to different estimates for RI. Also, RI can be estimated as a levered measure $\left(\mathrm{NI}_{\mathrm{t}}-\mathrm{r}_{\mathrm{e}} * \mathrm{BV}_{\mathrm{t}-1}\right)$ instead of an unlevered measure $\left(\mathrm{NOPAT}_{\mathrm{t}}-\mathrm{WACC} * \mathrm{IC}_{\mathrm{t}-1}\right)$.

We rerun the analyses in Tables 4 and 5 with the following alternate estimations of residual income. First, we use a net operating assets approach by netting out financial assets against debt while computing invested capital and correspondingly netting out interest income against interest expense while computing NOPAT. Second, we use a constant WACC of $12 \%$ for all firm-years, which implies that the term pertaining to change in WACC drops out of the decomposition. Third, we use a WACC that is constant across all firms at a given point in time but varies across time as the risk-free rate plus $6 \%$. Fourth, we compute the cost of equity for each firm using a factor model, controlling for the Fama and French (1993) factors for size (SMB) and book-to-market (HML) in addition to the market factor. ${ }^{13}$ Finally, we use a levered definition of residual income based on NI and BV, which implies

\footnotetext{
13 We run multi-factor estimation regressions to estimate firm specific factor loadings with respect to the Market Risk $\left(\mathrm{R}_{\mathrm{m}}-\mathrm{R}_{\mathrm{f}}\right.$ ), Size (SMB) and Book-to-Market (HML). To estimate the cost of equity, we assume the following risk premium for each of these factors based on historical realized premium: $R_{m}-R_{f}$ (6\%), SMB (2\%), HML (4\%).
} 


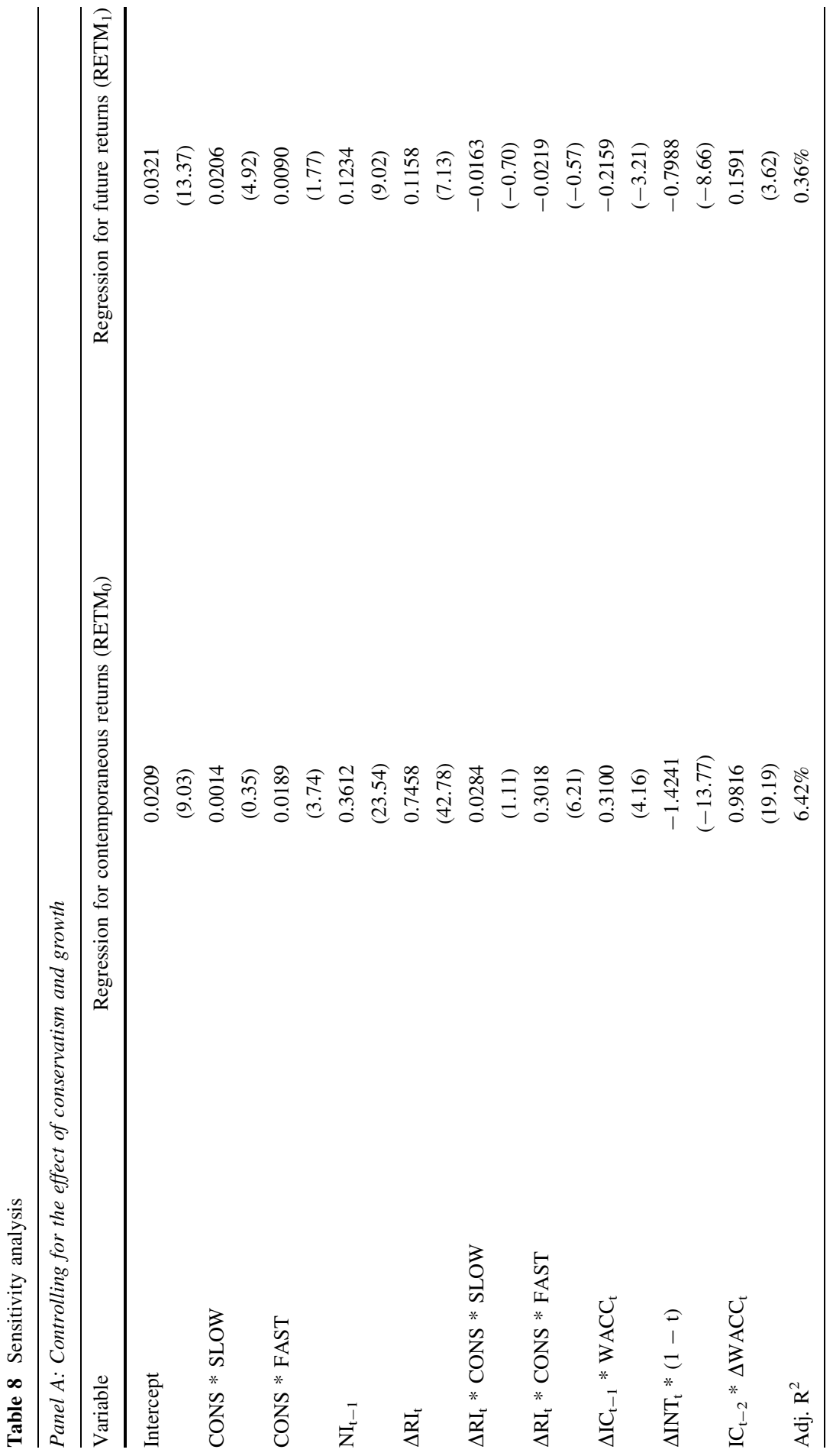




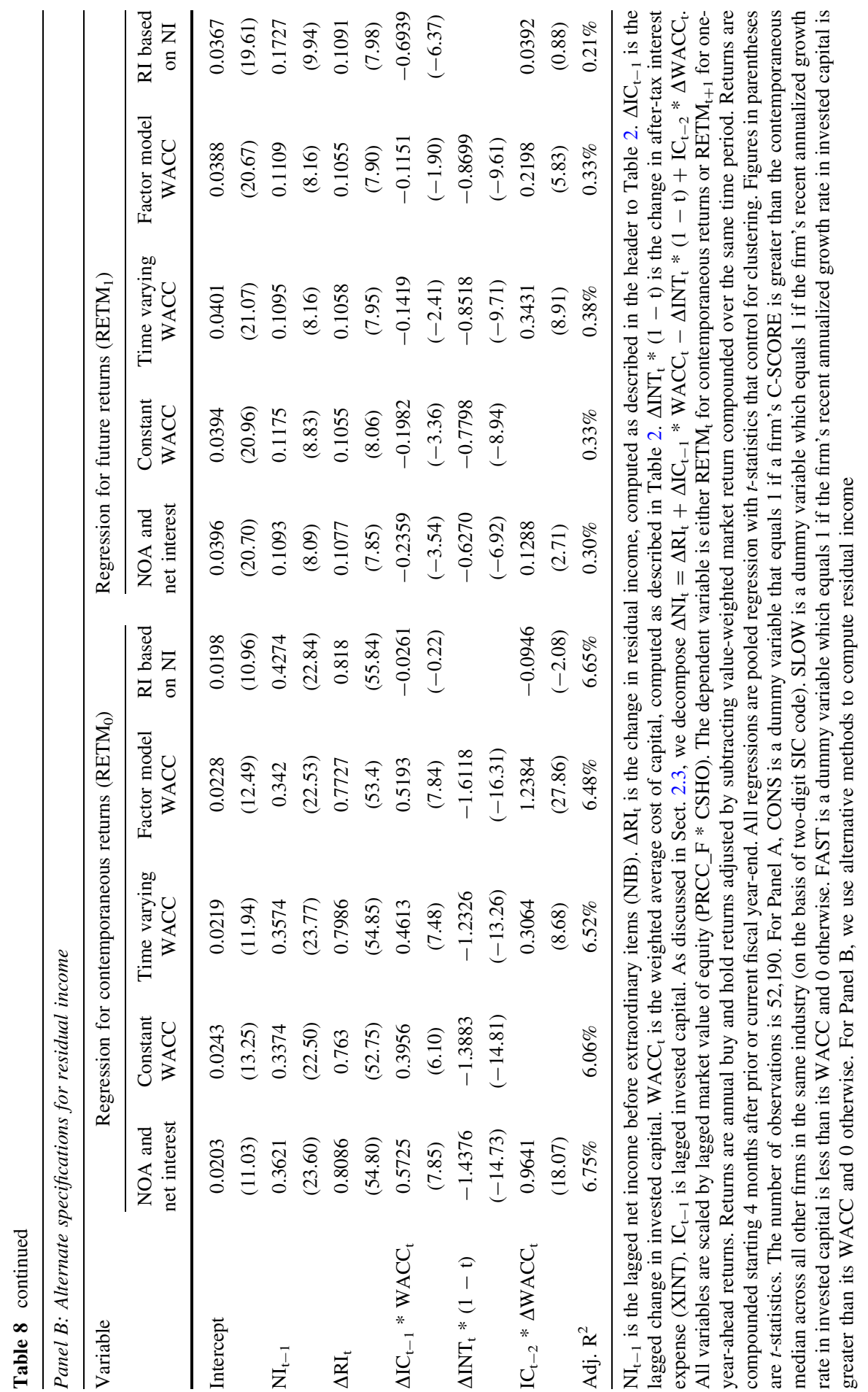


that the term pertaining to change in interest expense $\left(\Delta \operatorname{INT}_{\mathrm{t}} *(1-\mathrm{t})\right)$ is now a part of $\Delta \mathrm{RI}_{\mathrm{t}}$.

The results are presented in Panel B of Table 8. The first set of columns presents the regressions for contemporaneous results $\left(\mathrm{RETM}_{\mathrm{t}}\right)$. Using a net operating assets definition of RI increases explanatory power as the adjusted $\mathrm{R}^{2}$ increases to $6.75 \%$. Both $\Delta \mathrm{RI}_{\mathrm{t}}$ and $\Delta \mathrm{IC}_{\mathrm{t}-1} * \mathrm{WACC}_{\mathrm{t}}$ continue to be significant and positive. When we use a constant WACC, the expression related to the change in WACC $\left(\mathrm{IC}_{\mathrm{t}-2} * \Delta \mathrm{WACC}_{\mathrm{t}}\right)$ drops out of the regression, but both $\Delta \mathrm{RI}_{\mathrm{t}}$ and $\Delta \mathrm{IC}_{\mathrm{t}-1} * \mathrm{WACC}_{\mathrm{t}}$ continue to be significant and positive. The regression results are also robust when we use a WACC that is cross-sectionally constant but varies in time series, as well as the factor-model based WACC. Finally, when we use the levered definition of residual income based on net income, the coefficient on $\Delta \mathrm{RI}_{\mathrm{t}}$ continues to be significant but the coefficient on $\Delta \mathrm{IC}_{\mathrm{t}-1} * \mathrm{WACC}_{\mathrm{t}}$ is insignificant. ${ }^{14}$ The next set of columns presents the results for one-year-ahead returns $\left(\operatorname{RETM}_{t+1}\right)$. Across all five specifications, we continue to find strong evidence of drift with respect to $\Delta \mathrm{RI}_{\mathrm{t}}$ and reversal with respect to $\Delta \mathrm{IC}_{\mathrm{t}-1} * \mathrm{WACC}_{\mathrm{t}}$.

Given the vital importance of the computation of the cost of capital in the estimation of residual income, the stability of the results across the different methods might seem surprising. We surmise that two factors contribute to the robustness of the results. First, the impact of errors in the estimation of the cost of capital is likely mitigated in our analysis, as our decomposition focuses on the change in residual income and not the level of residual income. Second, the correlations increase further when we scale all values by size (lagged market capitalization). To illustrate, the Pearson (Spearman rank-order) correlation between the unscaled levels of RI computed as described in the paper using a CAPM approach and the RI computed using a constant WACC is only $0.72(0.67)$. However, the correlation between the changes in these unscaled measures is 0.93 (0.81). The correlation increases to $0.98(0.91)$ for the scaled values used in our analyses.

\subsubsection{Alternative multipliers for the RI-based decomposition}

Our approach towards using RI to refine the returns-earnings relationship makes certain assumptions, which may or may not be empirically valid. For instance, we label $\Delta \mathrm{IC}_{\mathrm{t}-1} * \mathrm{WACC}_{\mathrm{t}}$ as earnings growth from growth in invested capital. This represents earnings growth one would expect if the firm earned the cost of capital on new investment. If, in reality, incremental investment generates returns differing from cost of capital, then this component will be measured with error. Further, any measurement error in this component, will also affect other components in the decomposition, as the total of all components equals actual

\footnotetext{
${ }^{14}$ The insignificance of $\Delta \mathrm{IC}_{\mathrm{t}-1} * \mathrm{WACC}_{\mathrm{t}}$ is likely driven by multicollinearity. For the RI based on NI, the change in invested capital $\Delta \mathrm{IC}_{\mathrm{t}-1}$ equals change in book value, which is highly correlated with $\mathrm{NI}_{\mathrm{t}-1}$. Indeed, when we either drop $\mathrm{NI}_{\mathrm{t}-1}$ or replace it with $\mathrm{NI}_{\mathrm{t}}$, the coefficient on $\Delta \mathrm{IC}_{\mathrm{t}-1} * \mathrm{WACC}_{\mathrm{t}}$ is significant and positive.
} 
earnings growth. We use two approaches to examine the empirical effect of such error.

First we examine an alternate specification in which we multiply change in invested capital by the firm's lagged return on invested capital instead of WACC. Our expression for earnings growth from growth in invested capital is redefined as $\left(\mathrm{ROIC}_{\mathrm{t}-1} * \Delta \mathrm{IC}_{\mathrm{t}-1}\right){ }^{15}$ This assumes that the new investments will earn what the firm's existing assets have most recently earned. To ensure the consistency of the decomposition, we redefine the $\Delta \mathrm{RI}$ term (i.e., we subtract $\Delta \mathrm{IC}_{\mathrm{t}-1} * \mathrm{ROIC}_{\mathrm{t}-1}$ and add $\Delta \mathrm{IC}_{\mathrm{t}-1} * \mathrm{WACC}_{\mathrm{t}}$ to $\left.\Delta \mathrm{RI}_{\mathrm{t}}\right)$. Untabulated results for both contemporaneous returns as well as one-year-ahead returns are very similar to the presented results and suggest that the assumption that incremental investment earns the cost of capital is not critical.

Second, we use a specification with no multipliers with the following variables: $\mathrm{NI}_{\mathrm{t}-1}, \Delta \mathrm{RI}_{\mathrm{t}}, \Delta \mathrm{IC}_{\mathrm{t}-1}, \Delta \mathrm{INT}_{\mathrm{t}}$ and $\Delta \mathrm{WACC}_{\mathrm{t}}$. This specification no longer makes any assumption about the rate of return that investments earn but also does not preserve the additive decomposition of earnings growth. For contemporaneous returns, this regression has an adjusted $\mathrm{R}^{2}$ of $5.93 \%$, which is significantly lower than the $6.32 \%$ reported in Table 4, Panel B. This indicates that the structure imposed by our breakdown of earning growth is valuable, distinguishing our approach from that used in Harris and Nissim (2006). The coefficient on $\Delta \mathrm{RI}_{\mathrm{t}}$ continues to stay significant; however the coefficient on $\Delta \mathrm{IC}_{\mathrm{t}-1}$ is insignificant. ${ }^{16}$ For one-year-ahead returns, we continue to find a significant positive coefficient on $\Delta \mathrm{RI}_{\mathrm{t}}$ and a significant negative coefficient on $\Delta \mathrm{IC}_{\mathrm{t}-1}$. Hence, the result that the market underreacts to earnings growth from growth in RI and overreacts to earnings growth from growth in invested capital is unaltered.

\subsubsection{Robustness of hedge returns results}

We rerun the hedge returns tests in Table 7 using the alternate definitions of residual income described earlier. The results are very similar and not tabulated. In addition, we test if the hedge returns results are incremental to previously documented anomalies. Zhang (2007) shows that many accounting anomalies are related to the market's misperception about the implications of current growth for future growth. We control for three well-documented anomalies: accruals (Sloan 1996), capital expenditures (Titman et al. 2004) and external financing (Richardson and Sloan 2003). For brevity, the results are not tabulated but described below.

We first find that RI_GROW generates the second strongest return separation across quintiles $(8.1 \%)$, stronger than accruals and capital expenditures, but weaker than external financing (12.9\%). We then partition our sample into quintiles on the basis of the other anomaly variables, further partition on the basis of RI_GROW within each quintile, and test to see if the returns to the RI_GROW strategy persist

\footnotetext{
15 If lagged ROIC is negative, we continue to use WACC as the multiplier.

${ }^{16}$ The insignificance of $\Delta \mathrm{IC}_{\mathrm{t}-1}$ is also likely driven by multicollinearity. The correlation of $\Delta \mathrm{IC}_{\mathrm{t}-1}$ with $\mathrm{NI}_{\mathrm{t}-1}$ (0.60 Pearson, 0.38 Spearman) is greater than the correlation between $\Delta \mathrm{IC}_{\mathrm{t}-1} * \mathrm{WACC}_{\mathrm{t}}$ and $\mathrm{NI}_{\mathrm{t}-1}$ (0.53 Pearson, 0.31 Spearman). When we either drop $\mathrm{NI}_{t-1}$ or replace it with $\mathrm{NI}_{\mathrm{t}}$, the coefficient on $\Delta \mathrm{IC}_{\mathrm{t}-1}$ is significant and positive.
} 
within each quintile of the other variables. We find that the RI_GROW strategy is effective within all accrual quintiles, with the greatest return difference in firms with extreme accruals. The strategy is also effective within all capital expenditure quintiles and external financing quintiles with the greatest effectiveness for firms with highest capital expenditure and most external financing. This provides additional insight to the negative relationship between external financing and future returns demonstrated by Richardson and Sloan (2003), who interpret their finding as related to over-investment due to empire building. Our decomposition helps isolate firms least likely to waste the proceeds from external financing (highest RI_GROW) from firms most likely to do so (lowest RI_GROW).

\section{Conclusion}

Earnings and growth in earnings have been considered fundamental determinants of stock returns. However, accounting earnings has been criticized as an incomplete measure of firm profitability as it does not recognize the opportunity cost of the capital employed. Accounting scholars have long recommended the use of residual income (RI) as a proxy for economic profits, as it incorporates a charge for capital employed. In this paper, we decompose earnings growth into growth in RI, growth in invested capital, and other components. We use this RI-based decomposition to refine the empirical specification of the relationship between earnings and returns (Easton and Harris 1991).

We first find that the RI-based decomposition explains more of the crosssectional variation in stock returns than the traditional earnings and earnings changes specification. Further, while growth in both RI and invested capital have a positive association with returns, the coefficient on growth in RI is significantly greater. This suggests that the market contemporaneously considers the growth in RI component to be more valuable than the growth in invested capital component. Consistent with this, we find that the persistence of future earnings is increasing in the proportion of earnings growth due to growth in RI and decreasing in the proportion of earnings growth due to invested capital.

When we examine the relationship between the components of earnings growth and future returns, we find that, while the growth in RI component is positively associated with future returns, the growth in invested capital component is negatively associated with future returns. This suggests that markets contemporaneously underreact to growth in RI and overreact to growth in invested capital. A trading strategy based on a preference for earnings growth derived from growth in RI and an avoidance of earnings growth derived from growth in invested capital generates significant abnormal returns after controlling for known risk factors.

The positive relationship between growth in RI and stock returns is consistent with the contention in Anthony (1973) that RI is an informative metric of economic performance for shareholders. The negative relationship between growth from investment and future returns is consistent with prior research documenting negative returns after large investments in mergers and acquisitions (Roll 1986; Harding and Yale 2002; Bower 2001) and capital expenditures (Titman et al. 2004). 
Our paper contributes to the literature on the usefulness of RI vis-à-vis earnings by showing that, in contrast to prior research (Biddle et al. 1997; Chen and Dodd 1997), these two measures of performance need not be viewed as competing measures. The value of RI lies as an effective conditioning variable that helps us better understand the sources of earnings growth.

The results of this paper have interesting implications for future research. In a follow-up paper, Balachandran and Mohanram (2010) examine the association between CEO compensation and the RI-based decomposition of earnings growth developed in this paper. They find a greater association between CEO compensation and the invested capital component than the RI component, indicating that compensation committees place greater weight on earnings growth due to invested capital when determining CEO compensation. They conclude that the corporate boards of directors are, in a sense, incentivizing CEOs to destroy shareholder value.

While our paper highlights the importance of growth in RI, it does not identify the source of this growth. RI could increase either because existing assets are more profitable or because new investments generate additional profits. Separating out these two sources of RI growth is a potentially fruitful avenue for future research. Such identification is more likely in specific industries such as retail with extensive disclosure about same-store sales and profitability.

The results of the present paper apply to shareholders in the aggregate. An interesting extension would be to consider the implications of investor sophistication. For instance, does the presence of institutional shareholders reduce the drift with respect to growth in RI and also reduce the reversal with respect to growth in invested capital? Answers to such questions can help us build on the principal finding of this paper, that RI is an informative measure for shareholders.

Acknowledgments We would like to thank Stephen Penman, Tim Baldenius, Stefan Reichelstein (the editor), two anonymous referees and seminar participants at the AAA 2007 Annual Meeting, Columbia 2006 Burton workshop, Duke University, Istanbul Commerce University, Harvard University, The University of Houston, and Stanford University for their comments. Sudhakar Balachandran appreciates generous research support from Columbia Business School. Partha Mohanram appreciates research support from the Rotman School of Management at the University of Toronto and SSHRC-Canada. All errors are our own. Please contact Sudhakar Balachandran at svb34@columbia.edu with questions and comments.

\section{References}

Ali, A., \& Zarowin, P. (1992). The role of earnings levels in annual earnings-returns studies. Journal of Accounting Research, 30(2), 286-296.

Anthony, R. (1973). Accounting for the cost of equity. Harvard Business Review, 51, 88-102.

Balachandran, S. (2006). How does residual income affective investments? The role of prior performance measures. Management Science, 53, 338-394.

Balachandran, S., \& Mohanram, P. (2010). Are CEOs compensated for value destroying growth in earnings. Review of Accounting Studies, 15, 545-557.

Baldenius, T., Fuhrmann, G., \& Reichelstein, S. (1999). Zurück zu EVA. Betriebswirtschaftliche Forschung und Praxis, 1(99), 53-65.

Bernard, V. (1995). The Feltham-Ohlson framework: Implications for empiricists. Contemporary Accounting Research, 11, 733-747.

Bernard, V., \& Thomas, J. (1989). Post-earnings-announcement drift: Delayed price response or risk premium? Journal of Accounting Research Supplement, 27, 1-36. 
Biddle, G., Bowen, R., \& Wallace, J. (1997). Does EVA beat earnings? Evidence on the associations with stock returns and firms values. Journal of Accounting and Economics, 24, 301-306.

Bower, J. (2001). Not all M\&As are alike-and that matters. Harvard Business Review, 79(3), 93-101.

Chen, S., \& Dodd, J. (1997). Economic value added $\left(\mathrm{EVA}^{\mathrm{TM}}\right)$ : An empirical examination of a new corporate performance measure. Journal of Management Issues, 9, 319-333.

Chordia, T., \& Shivakumar, L. (2006). Earnings and price momentum. Journal of Financial Economics, $80,627-656$

Dearden, J. (1972). How to make incentive plans work. Harvard Business Review, 50(4), 117-122.

Dechow, P., Kothari, S., \& Watts, R. (1998). The relation between earnings and cash flows. Journal of Accounting and Economics, 25, 133-168.

Dutta, S., \& Reichelstein, S. (2002). Controlling investment decisions: Depreciation-and capital charges. Review of Accounting Studies, 7(2), 253-281.

Easton, P., \& Harris, T. (1991). Earnings as an explanatory variable for returns. Journal of Accounting Research, 29, 19-36.

Easton, P., Harris, T., \& Ohlson, J. (1992). Aggregate accounting earnings can explain most of security returns: The case of long return intervals. Journal of Accounting and Economics, 15, 119-142.

Elgers, P., \& Lo, M. (1994). Reduction in analysts' annual earnings forecast errors using information in prior earnings and security return. Journal of Accounting Research, 32, 290-303.

Fama, E., \& French, K. (1993). Common risk factors in the returns on stocks and bonds. Journal of Financial Economics, 33, 3-56.

Fama, E., \& MacBeth, J. (1973). Risk, return and equilibrium: Empirical tests. Journal of Political Economy, 81, 607-636.

Feltham, G., \& Ohlson, J. (1995). Valuation and clean surplus accounting for operating and financial activities. Contemporary Accounting Research, 11(2), 689-731.

Frankel, R., \& Lee, C. (1998). Accounting valuation, market expectation and cross-sectional stock returns. Journal of Accounting and Economics, 25, 283-319.

Gebhardt, W., Lee, C., \& Swaminathan, B. (2001). Toward an implied cost of capital. Journal of Accounting Research, 39, 135-176.

Ghosh, A., Gu, Z., \& Jain, P. (2005). Sustained earnings and revenue growth, earnings quality, and earnings response coefficients. Review of Accounting Studies, 10, 33-57.

Harding, D., \& Yale, P. (2002). Discipline and the dilutive deal. Harvard Business Review, 80(7), 18-20.

Harris, T., \& Nissim, D. (2006). The differential value implications of the profitability and investment components of earnings. Working Paper, Columbia University.

Horngren, C., Datar, S., \& Foster, G. (2006). Cost accounting: A managerial emphasis. New Jersey: Prentice Hall.

Morse, D., \& Zimmerman, J. (1997). Managerial accounting. Chicago, IL: Richard D. Irwin.

Newey, W., \& West, K. (1987). A simple positive semi-definite, heteroskedasticity and autocorrelation consistent covariance matrix. Econometrica, 55, 775-804.

Ohlson, J. (1995). Earnings, book values, and dividends in equity valuation. Contemporary Accounting Research, 11(2), 661-687.

Ohlson, J., \& Juettner-Nauroth, B. (2005). Expected EPS and EPS growth as determinants of value. Review of Accounting Studies, 10, 349-365.

Penman, S., \& Zhang, X. (2002). Accounting conservatism, the quality of earnings, and stock returns. The Accounting Review, 77, 237-264.

Rajan, M., Reichelstein, S., \& Soliman, M. (2007). Conservatism, growth and return on investment. Review of Accounting Studies, 12, 325-370.

Reichelstein, S. (1997). Investment decisions and managerial performance evaluation. Review of Accounting Studies, 2(2), 157-180.

Richardson, S., \& Sloan, R. (2003). External financing, capital investment and future stock returns. Working Paper, University of Pennsylvania.

Rogerson, W. (1997). Intertemporal cost allocation and managerial investment incentives: A theory explaining the use of economic value added as a performance measure. Journal of Political Economy, 105(4), 770-779.

Roll, R. (1986). The hubris hypothesis of corporate takeovers. Journal of Business, 59, 197-216.

Sloan, R. (1996). Do stock prices fully reflect information in accruals and cash flows about future earnings? The Accounting Review, 71, 289-315.

Solomons, D. (1965). Divisional performance measurement and control. Homewood, IL: Richard D. Irwin. 
Titman, S., Wei, K., \& Xie, F. (2004). Capital investments and stock returns. Journal of Financial and Quantitative Analysis, 39, 677-700.

Vuong, Q. (1989). Likelihood ratio tests for model selection and non-nested hypotheses. Econometrica, 57, 307-333.

Wallace, J. (1997). Adopting residual income-based compensation plans: Do you get what you pay for? Journal of Accounting and Economics, 24, 275-300.

Zhang, F. (2007). Accruals, investment, and the accrual anomaly. The Accounting Review, 82, 1333-1363. 